\title{
Using nanogranitoids and phase equilibria modeling to unravel anatexis in the crustal footwall of the Ronda peridotites (Betic Cordillera, S Spain)
}

Omar Bartoli ${ }^{1 *}$, Antonio Acosta-Vigil ${ }^{1,2}$, Lucie Tajčmanová ${ }^{3}$, Bernardo Cesare $^{1}$, Robert J. Bodnar ${ }^{4}$

${ }^{1}$ Dipartimento di Geoscienze, Università di Padova, Padova, 35131, Italy

${ }^{2}$ Instituto Andaluz de Ciencias de la Tierra, Consejo Superior de Investigaciones Científicas and Universidad de Granada, Avda. de Las Palmeras n 4, Armilla 18100, Granada, Spain

${ }^{3}$ Department of Earth Sciences, Swiss Federal Institute of Technology, Zurich, 8092, Switzerland

${ }^{4}$ Department of Geosciences, Virginia Tech, Blacksburg, Virginia 24061, U.S.A

* corresponding author, omar.bartoli@unipd.it

Phone: +39-0498279148 


\section{Abstract}

Anatexis in the crustal footwall of Ronda peridotites (Betic Cordillera, S Spain) is apparently related to the hot emplacement of this mantle slab over metasedimentary rocks. In this study we combine the analysis of melt inclusions (MI) and phase equilibria calculations on quartzo-feldspathic mylonites (former migmatites) occurring at the contact with the mantle rocks, in the region of Sierra Alpujata (Ojén unit). The goal is to better characterize anatexis in these rocks, and to provide new constraints on the geodynamic evolution of the crustal footwall. Such data are important for understanding the mechanisms of crustal emplacement of the mantle rocks. The quartzo-feldspathic mylonites are characterized by the mineral assemblage $\mathrm{Qtz}+\mathrm{Pl}+\mathrm{Kf} s+\mathrm{Sil}+\mathrm{Grt}+\mathrm{Ilm}+\mathrm{Bt} \pm \mathrm{Ap} \pm \mathrm{Gr}$. Clusters of $\mathrm{MI}$ are observed both at the core and towards the rim of peritectic garnet. In each cluster, MI range from totally glassy to nanogranitoids, consisting of $\mathrm{Qtz}+\mathrm{Kfs}+\mathrm{Bt}+\mathrm{Ms}+\mathrm{Pl}$ aggregates. The trapped melt is leucogranitic and peraluminous with variable $\mathrm{Na}_{2} \mathrm{O} / \mathrm{K}_{2} \mathrm{O}$ values and low $\mathrm{H}_{2} \mathrm{O}$ contents $(\approx 2-4$ wt $\%)$. Phase equilibria modelling in the $\mathrm{MnO}-\mathrm{Na}_{2} \mathrm{O}-\mathrm{CaO}-\mathrm{K}_{2} \mathrm{O}-\mathrm{FeO}-\mathrm{MgO}-\mathrm{Al}_{2} \mathrm{O}_{3}-\mathrm{SiO}_{2}-\mathrm{H}_{2}-\mathrm{TiO}_{2}-\mathrm{O}_{2}-\mathrm{C}$ (MnNCaKFMASHTOC) system with graphite-saturated fluid constrains the $P-T$ conditions of melting at $\approx 6 \mathrm{kbar}, \approx 820{ }^{\circ} \mathrm{C}$. MI data support the fluid-absent character of melting. The investigated MI represent the primary anatectic melts produced during prograde anatexis of the host rocks via biotite dehydration melting. Field, compositional and textural observations indicate that mylonitic migmatites represent strongly deformed former diatexites. The comparison between the new data and some recently published information on migmatites located further from the contact with the peridotites and towards the bottom of the crustal footwall, raises some important issues which question the previously proposed geodynamic models for this region. Among them, i) the crustal footwall at Sierra Alpujata constitutes an inverted metamorphic sequence, not only in terms of temperature but also in pressure, and ii) the Ojén unit does not seem to represent a coherent high-P portion of a continental subduction system. 
Key words: crustal anatexis, melt inclusions, nanogranitods, phase equilibria modeling, Ronda peridotites

\section{Introduction}

Progress in the investigation of high-grade, partially-melted crystalline basements has been made in the last decade by studying melt and fluid inclusions (e.g., Cesare et al., 2009; Frezzotti and Ferrando, 2015), as well as through phase equilibria modelling based on large, internally consistent thermodynamic datasets (e.g., Johnson et al., 2008; White et al., 2007, 2011). Of particular importance is the discovery of primary melt inclusions (MI) hosted in peritectic minerals of regionally metamorphosed crustal rocks, which has been described in recent papers (reviewed by Cesare et al., 2015 and Bartoli et al, 2016). Being trapped by growing peritectic phases at suprasolidus conditions, these MI represent a window into the pre-peak anatectic history of partially-melted terranes (AcostaVigil et al., 2010), and may provide key microstructural and compositional information on crustal anatexis, such as which mineral grew in the presence of melt, if a rock has melted, when a rock has melted, the mechanisms and nature of the melting process, and the timeframes of melt production and segregation (Cesare et al., 2015).

The Ronda peridotites, the largest known exposure of subcontinental lithospheric mantle on the Earth surface $\left(\approx 300 \mathrm{~km}^{2}\right.$; Obata, 1980), crop out in the Internal Zones of the Alpine Betic Cordillera (southern Spain; Fig. 1a), primarily in the massifs of Sierra Bermeja, Sierra Alpujata and Carratraca (Fig. 1b). The peridotites occur as km-thick slabs sandwiched between mostly metasedimentary crustal rocks (metapelites and metagreywackes), which are in turn characterized by their increasing metamorphic grade, degree of melting and intensity of deformation towards the mantle rocks (e.g., Loomis, 1972; Westerhof, 1975; Tubía et al., 1997, 2013; Acosta-Vigil et al., 2001, 2014, 2016; Platt et al., 2003; Esteban et al., 2008; Barich et al., 2014). Whereas partial melting of the metasedimentary 
rocks above the peridotite has been related to decompression (Platt et al., 2003), in the crustal footwall it has been related to the hot thrusting of the mantle slab over metasedimentary rocks, resulting in a dynamothermal aureole (Tubía et al., 1997, 2013). Although several studies have examined in detail the structural evolution and kinematics of the crustal footwall of the Ronda peridotites (Tubía et al., 1997, 2013; Cuevas et al., 2006; Esteban et al., 2008), anatexis throughout this complex crustal sequence is still poorly characterized, particularly close to the contact with the mantle slice. The lack of modern petrological studies on the crustal envelope, together with recent geochronological studies showing the existence of pre-Alpine mineral associations and fabrics in the western Betic Cordillera (e.g. AcostaVigil et al., 2014; Massonne, 2014; Sánchez-Navas et al., 2014), have renewed an old debate on the geodynamic evolution of this important sector of the orogen characterized by the presence of subcontinental mantle slabs (e.g., Platt and Vissers, 1989; Zeck et al., 1992; Michard et al., 1997). Melting in the crustal footwall is apparently related to the crustal emplacement of the mantle slab (Westerhof, 1975; Torres-Roldán, 1983; Tubía et al., 1997). Therefore, a detailed characterization of metamorphic conditions and the nature of anatexis is a key step to the constraining the mechanism of emplacement of the Ronda peridotites and to the understanding of the tectono-metamorphic evolution of the whole orogen. In this contribution, we report the occurrence and characteristics of MI hosted in peritectic garnet of graphite-bearing, quartzo-feldspathic mylonites cropping out in the crustal footwall of the Ronda peridotites (Sierra Alpujata, Ojén unit), close to the contact with the mantle rocks. By combining the microstructural and compositional investigation of MI with phase equilibria modelling of the host rock we obtain new and robust data on anatexis near the contact with the peridotites. These data are then compared with recently published information on MI in migmatites from the same unit though located further from the contact with the peridotites, in order to discuss the reliability of the currently proposed models on the emplacement of the mantle slab. 


\section{Geological setting}

The Betic Cordillera (southern Spain) represents the westernmost part of the peri-Mediterranean Alpine orogen, formed during the N-S to NW-SE convergence of the African and Iberian plates from Late Cretaceous to Early Neogene times (Dewey et al., 1989). The Internal Zone of this orogenic belt shows mainly metamorphic rocks of Paleozoic to Paleogene age constituting several units distributed in two main tectonic complexes, the Alpujárride Complex at the bottom and Maláguide Complex at the top (e.g. Platt et al., 2013, and references therein) (Fig. 1b). The Ronda peridotites form the lower portion of the Los Reales unit, which is the structurally highest Alpujárride unit (Navarro-Vilá and Tubía, 1983; Tubía, 1988). The mantle rocks are emplaced over the Guadaiza and Ojén Alpujárride units (Fig. 1b), constituting the footwall of the Ronda peridotites (Navarro-Vilá and Tubía, 1983). The basal contacts between mantle and crustal rocks are HT shear zones formed by mylonites (Esteban et al., 2008; Tubía et al., 1997, 2013). The Guadaiza and Ojén units show differences in lithology, peak pressure and, importantly, $P-T$ path and kinematics, with the Ojén unit recording decompression from $\geq 15 \mathrm{kbar}$ at $\geq 730^{\circ} \mathrm{C}$ and dominant top-to-the-ENE sense of shear, and the Guadaiza unit showing heating to $700-800{ }^{\circ} \mathrm{C}$ at 4-6 kbar and top-to-the-NNW sense of shear (Tubía et al., 1997; Esteban et al., 2008; Acosta-Vigil et al., 2014; and references therein). The relationship between these units is unclear, and they may have been juxtaposed through the Albornoque strike-slip subvertical fault (Tubía, 1988). In general isograds in these crustal sequences are roughly parallel to the lithological contacts and to the regional foliation (Westerhof, 1975; Tubía et al., 2013; Acosta-Vigil et al., 2014).

The rocks studied in this contribution are from the Ojén unit and consist of metasedimentary quartzo-feldspathic mylonites from the metamorphic footwall of the Sierra Alpujata massif (Figs. 1, 2), located $\sim 50$ m below the contact with the peridotite (Fig. 2). The Ojén unit shows along-strike variations which have been interpreted as large-scale boundin-like structures related to the late exhumation stages of the Ronda peridotites (Tubía et al., 2013). The most complete sequence has a 
thickness of $\approx 700-800 \mathrm{~m}$ (Fig. 2). Below we describe this unit from the top to the bottom using field and structural data reported in Tubía (1988) and Tubía et al. $(1997,2013)$. The sequence is made of mylonites, migmatites, schists and marbles (Fig. 2). At 200-300 m from the contact with the peridotites, the crustal rocks are strongly deformed and have been interpreted as HT quartzo-feldspathic mylonites. These rocks are characterized by ENE-trending mineral lineations, and $40^{\circ}$ to $60^{\circ} \mathrm{S}$-dipping mylonitic foliation $\left(\mathrm{S}_{\mathrm{myl}}\right)$ subparallel to the contact between crustal and mantle rocks; sigmoidal shear bands and S-C microstructures indicate a top-to-the-ENE shearing. According to Tubía et al. (1997), mylonites have been intruded by granitic bodies up to $100 \mathrm{~m}$ think, roughly concordant with $\mathrm{S}_{\mathrm{myl}}$. The central part of the unit comprises migmatites, with diatexites on top of banded migmatites and migmatized leucocratic gneisses. Decimetric to decametric amphibolite lenses that preserve eclogitic relicts, recording peak conditions of $\geq 15 \mathrm{kbar}$ and $\geq 730^{\circ} \mathrm{C}$, have been described towards the bottom of the migmatitic sequence (Fig. 2; Tubía and Gil-Ibarguchi, 1991). A low-temperature shear zone (ENEward shearing) separates banded migmatites and Sil-bearing, amphibolite facies schists; here migmatites are intensely retrogressed. In addition, isolated shear zones have also been described within the crustal footwall, for example between amphibolite lenses and banded migmatites. The bottom of the crustal footwall is formed by amphibolite-facies marbles.

Regarding deformation, the oldest event recorded in the Ojén unit, $\mathrm{D}_{1}$, is preserved as a residual schistosity $\left(\mathrm{S}_{1}\right)$ within garnet from the schists; the subsequent deformation phase $\mathrm{D}_{2}$ produced the main schistosity $\mathbf{S}_{2}$ observed in schists and, apparently, in the banded gneisses also (Fig. 2, Tubía, 1988). $\mathbf{S}_{2}$ can be affected by open folds as a result of a younger deformation event $\mathrm{D}_{3}$ (Tubía, 1988). The melting process responsible for the formation of anatectic melt and cordierite in the migmatitic sequence is considered to be related to a younger, low-P post- $\mathrm{D}_{3}$ static event (Tubía, 1988). Finally, mylonitization at the contact with the peridoties and the penetrative mylonitic foliation $\left(\mathrm{S}_{\mathrm{myl}}\right)$ is connected to a subsequent deformation phase $\mathrm{D}_{4}$ (Tubía, 1988). $\mathrm{S}_{\mathrm{myl}}$ is subparallel to the main foliation $\mathrm{S}_{2}$ in banded 
migmatites and schists, and axes of folds developed during $\mathrm{D}_{3}$ are parallel to the mineral lineation observed in the mylonites (Tubía et al., 1997). Following Tubía (1988), migmatization occurred after inversion of the sequence and during the emplacement of the peridotites, and migmatization and mylonitization likely represent the continuation in time of the metamorphic and structural evolution recorded by the schists at the bottom of the sequence $\left(D_{1}\right.$ through $\left.D_{3}\right)$.

The intrusion of the amphibolite/eclogite protolith into the metasedimentary rocks was dated (U-Pb SHRIMP zircon) at $\approx 184 \mathrm{Ma}$ (Sanchez-Rodrigez and Gebauer, 2000). Early Miocene deformed and undeformed granitoid dikes intrude the peridotite slab (Fig. 2; Priem et al., 1979; Tubía et al., 1997; Acosta, 1998; Sánchez-Rodríguez, 1998; Cuevas et al., 2006; Esteban et al., 2011a). The timing of the high-temperature metamorphism and anatexis in the crustal footwall of the Ronda peridotites, however, is controversial, as it has been ascribed to either the Alpine and/or Variscan orogenies (Acosta, 1998; Sánchez-Rodríguez, 1998; Sánchez-Rodríguez and Gebauer, 2000; Esteban et al., 2011a; Acosta-Vigil et al., 2014).

The limited $P-T$ data available indicate that rocks from different levels of the Ojén unit record different decompression paths. Mylonites at the contact with the peridotites record an evolution from $\approx 8 \mathrm{kbar}$ and $\approx 800^{\circ} \mathrm{C}$ to $5.5 \mathrm{kbar}$ and $\approx 685^{\circ} \mathrm{C}$ (Westerhof, 1975 , 1977; Tubía et al., 1997). The eclogite/amphibolite layers within the migmatites record decompression from $\geq 15 \mathrm{kbar}$ and $\geq 730{ }^{\circ} \mathrm{C}$ to $\approx 5-8$ kbar and $\approx 700-750{ }^{\circ} \mathrm{C}$ (Tubía et al., 1997). In addition, Bartoli et al. (2013c) have recently determined peak conditions of $4.5-5.0 \mathrm{kbar}$ and $660-700{ }^{\circ} \mathrm{C}$ for quartzo-feldspathic metatexites at the base of migmatitic sequence (see below) and at the contact with the eclogite/amphibolite layers.

\section{Analytical techniques}

Back-scattered electron (BSE) imaging and semi-quantitative energy dispersive spectroscopy (EDS) were carried out on crystallized and glassy melt inclusions using a CAM SCAN MX2500, equipped 
with $\mathrm{LaB}_{6}$ cathode, at the Dipartimento di Geoscienze, Università di Padova (Italy) and a Jeol JSM6500F thermal Field Emission Scanning Electron Microscope (FESEM), at INGV (Istituto Nazionale di Geofisica e Vulcanologia), Rome, Italy. Elemental X-ray maps were acquired at 20 and 15kV accelerating voltage and at variable magnifications, in the range 5000-6000X, depending on the MI size, using the FEI Quanta 600 FEG equipped with a Bruker EDX-Silicon Drifted Detector, at the Nanoscale Characterization and Fabrication Laboratory, Institute for Critical Technology and Applied Science, Virginia Tech, USA.

The compositions of biotite, feldspar and glass were obtained using a Jeol JXA 8200 Superprobe at the Dipartimento di Scienze della Terra, Università di Milano (Italy). Analytical parameters for minerals were: $15 \mathrm{kV}$ accelerating voltage, $5 \mathrm{nA}$ current, counting time of $30 \mathrm{~s}$ on peak and $10 \mathrm{~s}$ on background. The analytical procedure for the analyses of glass followed the recommendations of Morgan and London (1996, 2005); analytical parameters were: $15 \mathrm{kV}$ accelerating voltage, 2 nA current, $1 \mu \mathrm{m}$ beam diameter and a counting time of $10 \mathrm{~s}$ on peak and $2 \mathrm{~s}$ on background. Sodium, $\mathrm{K}$, $\mathrm{Al}$ and $\mathrm{Si}$ were analyzed first and concurrently. Owing to $\mathrm{Na}$ loss during electron microprobe analysis of rhyolitic glasses with effects also on $\mathrm{K}, \mathrm{Al}$ and $\mathrm{Si}$, concentrations were corrected by analyzing leucogranitic glass standards (Morgan and London, 1996, 2005). Details concerning the application of correction factors and the composition of the standard glasses are given by Ferrero et al. (2012) and Bartoli et al. (2013a, b). Garnet compositions were determined using the Cameca SX50 microprobe of the C.N.R.-I.G.G. (Consiglio Nazionale delle Ricerche-Istituto di Geoscienze e Georisorse) at the Dipartimento di Geoscienze, Università di Padova, Italy. Measurements were performed using a 20 kV accelerating voltage, $20 \mathrm{nA}$ beam current, and counting times of $10 \mathrm{~s}$ on peak and $5 \mathrm{~s}$ on background. Natural and synthetic silicates and oxides were used as standards.

\section{Sample description}




\subsection{Field relationships}

Here we integrate the field description reported in Section 2 with our observations; this integration is shown in Fig. 2. In detail, the mylonitic package beneath the Ronda peridotite at Sierra Alpujata is composed of $\approx 30 \mathrm{~m}$ of rutile-bearing metapelitic granulites at the contact with the mantle rocks, and $\approx 200$ m of apparently rutile-free, and mostly metasedimentary quartzo-feldspathic mylonites, that grade progressively downwards into metasedimentary diatexites, at the top of the migmatitic sequence, and metatexites, at the bottom (Fig. 2). The metatexites would be equivalent to the banded migmatites and migmatized gneisses of Tubía (1988) and Tubía et al. (1997) (see above). Based on mineral proportions and whole-rock geochemistry, both morphological types of migmatites have been grouped into pelitic and quartzo-feldspathic (Acosta, 1998; Acosta et al., 2001). Diatexites can be nebulitic, schlieric or schollen rocks; nebulitic varieties contain fragments of paleosome rotated into different orientations (see also Tubía, 1988), whereas a magmatic foliation $\left(S_{\mathrm{mag}}\right)$ defined by oriented elongated fragments of paleosome, cm-thick leucosomes and K-feldspar megacrysts develops in the schlieric migmatites (Fig. 2; see also Acosta, 1998). Metatexites, located above the schists, mostly appear as stromatic migmatites with garnet-bearing undeformed leucosomes that define $\mathrm{S}_{2}$ (Acosta, 1998; Bartoli et al., 2013c). Locally, metatexites are folded and the main foliation is obliterated by axial-planar cordierite-bearing and undeformed patches, representing cordierite-neosomes (Acosta, 1998; see below). $\mathrm{S}_{\mathrm{myl}}, \mathrm{S}_{\mathrm{mag}}$, and $\mathrm{S}_{2}$ are all subparallel (Fig. 2).

In this contribution we have investigated in detail the microstructures, MI and petrology of quartzo-feldspathic mylonites located $\sim 50 \mathrm{~m}$ below the contact with the peridotite (Fig. 2). They occur as deformed, banded rocks composed of alternating fine- to medium-grained leucocratic bands (30-50 vol.\%) and fine-grained mesocratic bands (50-70 vol.\%) (Fig. 3a, b). The main foliation $\mathrm{S}_{\mathrm{myl}}$ strikes $\mathrm{N} 70^{\circ} \mathrm{E}$ and dips $60^{\circ}$ to $\mathrm{S}$, in agreement with what observed in other structural stations (Fig. 1c). 


\subsection{Petrography}

The fine-grained matrix of the mesocratic bands (grain size of $\approx 20-200 \mu \mathrm{m}$ ) is composed mostly by $\mathrm{Qtz}+\mathrm{Kfs}+\mathrm{Pl}+\mathrm{Sil}$ (mineral abbreviations after Kretz, 1983) and minor biotite and ilmenite, and includes frequent porphyroclasts of garnet (0.5-3 $\mathrm{mm}$ in diameter) and K-feldspar (up to $2 \mathrm{~cm}$ in size) (Fig. 3cf). Some K-feldspar porphyroclasts have an augen-like appearance and may show simple twinning (Fig. 3d). Rare irregularly shaped domains of quartz containing euhedral plagioclase and biotite may be present in the strain shadows of these crystals (Fig. 3e). Locally sillimanite may occur as $\approx 150-200 \mu \mathrm{m}$ prismatic crystals (Fig. 3f). Accessory phases are graphite, apatite, zircon and monazite. Garnet modal proportion is $\approx 5-10$ vol.\%, whereas that of biotite never exceeds $2-5$ vol.\%. The main foliation $\left(\mathrm{S}_{\text {myl }}\right)$ is defined by the alignment of sillimanite folia, ribbons of quartz, minor elongated crystals of biotite and ilmenite, and the alternation of sillimanite-rich and leucocratic layers (Fig. 3b, c). Graphite ( $<1$ vol.\%) is randomly distributed in the matrix, whereas apatite and ilmenite are generally associated with sillimanite and biotie. Garnet and K-feldspar porhyroclasts may contain mineral inclusions of biotite, quartz, plagioclase, sillimanite and graphite, often not oriented. Garnet frequently contains MI (see below). In some garnet crystals, rare mineral inclusions together with abundant MI define an internal foliation having a sigmoidal to spiral-like shape (see below). Biotite often grew in the strain shadows associated with garnet, partially to totally replacing it (Fig. 3f). In the fine-grained matrix, quartz shows cuspate-lobate boundaries and subgrains (Fig. 3g), sometimes with approximately square subgrains resembling chessboard patterns (Fig. 3h), formed in response to grain boundary migration recrystallization.

Leucocratic bands may show a high lateral continuity with thicknesses of $1-50 \mathrm{~cm}$, and are mainly composed of $\mathrm{Pl}+\mathrm{Kfs}+\mathrm{Qtz}$ ranging in size from $\approx 300 \mu \mathrm{m}$ up to $2 \mathrm{~mm}$. Sillimanite, garnet and biotite are accessory phases. Crystals in these bands are often rounded and/or elongated, and mantled by a fine- 
grained mesocratic matrix (Fig. 3 i). Locally, leucocratic bands may contain igneous microstructures, such as feldspars displaying euhedral shapes with straight boundaries (Fig. 3j).

The apparently progressive change downwards observed in the field from mylonites at the contact with the peridotites to the different morphological types of migmatites towards the lower part of the sequence (Fig. 2), is also reflected in mineral proportions, mineral chemistry and microstructures of the metasedimentary rocks. For instance, and considering similar bulk rock compositions (Table 1), the above described microstructures in quartzo-feldspathic mylonites contrast with those in quartzofeldspathic stromatic metatexites towards the bottom of the sequence, which are characterized by i) larger grain size of the matrix minerals (up to $\approx 1.5 \mathrm{~mm})$, ii) higher proportions of biotite $(\approx 8-10$ vol.\%), iii) lower proportions of garnet ( $\approx 2-5$ vol.\%) occurring as small (50-200 $\mu \mathrm{m}$ in diameter) crystals, iv) lower crystallinity of sillimanite which is always present as fibrolite, v) a foliation defined by abundant oriented biotite generally clustered with sillimanite and vi) the presence of thin and discontinuous garnet-bearing leucosomes parallel to the main foliation and typically with subhedral igneous microstructures (Fig. 4a, b; Bartoli et al., 2013c). In addition the metatexites locally show cordierite-neosomes which obliterate the main foliation and are discordant with respect to the garnetbearing leucosomes (Fig. 4a, Acosta, 1998). Here apparently peritectic cordierite coexists with euhedral crystals of feldspars and cuspate domains of quartz (Fig. 4c) suggesting that these portions are former patches of anatectic melt (Sawyer, 2008).

\subsection{Mineral chemistry}

Biotite composition in quartzo-feldspathic mylonites is variable, particularly regarding $\mathrm{Ti}$ and $X_{\mathrm{Mg}}$ that range from 0.21 to 0.69 apfu and from 0.43 to 0.53 , respectively (Table 1 ). This variability displays some systematic patterns as a function of the microstructural position. Biotite replacing garnet has higher $X_{\mathrm{Mg}}(0.47-0.53)$ and lower Ti content (0.21-0.55 apfu) than biotite in the mesocratic matrix 
$\left(X_{\mathrm{Mg}}=0.43-0.50 ; \mathrm{Ti}=0.51-0.69 \mathrm{apfu}\right)$. Inclusions of biotite in garnet and K-feldspar porphyroclasts are very similar in composition to biotite in the matrix. In addition, biotite replacing garnet shows higher $\mathrm{F}$ contents (up to $1.5 \mathrm{wt} \%$ ) than biotite in the rock matrix (up to $1.0 \mathrm{wt} \%$ ). $\mathrm{Cl}$ is low in all investigated crystals $(0.2-0.6 \mathrm{wt} \%)$.

Garnet is an almandine-rich solid solution (Table 1) and no chemical variations were observed between either MI-free and MI-bearing garnet, or garnet in mesocratic and leucocratic portions of the rock. Garnet cores in the mesocratic matrix and leucocratic bands have a similar composition (Alm 72 $\left.{ }_{75} \operatorname{Prp}_{20-23} \mathrm{Sps}_{02-03} \mathrm{Grs}_{02-03} ; X_{\mathrm{Mg}}=0.21-0.24\right)$. Most of the garnets are unzoned, with $\mathrm{Fe}, \mathrm{Mg}, \mathrm{Mn}$ and $\mathrm{Ca}$ being fairly homogeneous throughout the crystal. Garnet rims have a composition of Alm72-76Prp2024Sps02-03Grs02 $\left(X_{\mathrm{Mg}}=0.21-0.25\right)$. Only garnets in contact with biotite are zoned: almandine and spessartine components increase from core to rim, whereas pyrope component decreases (Table 1). Thus, garnet rims in contact with biotite display a composition of Alm76-79Prp15-20Sps03-05Grs02, with $X \mathrm{Mg}=0.17-0.20$. Calcium content is always low and constant $(\mathrm{CaO} \approx 0.7 \mathrm{wt} \%)$.

Plagioclase within the mesocratic matrix has a composition of $\mathrm{Ab}_{66-73} \mathrm{An}_{25-32} \mathrm{Or}_{01-02}$, whereas crystals slightly more albitic and richer in orthoclase component $\left(\mathrm{Ab}_{70-76} \mathrm{An}_{21-26} \mathrm{Or}_{03-05}\right)$ are present in the leucocratic bands (Table 1). Plagioclase grains included in garnet porphyroclasts display compositions $\left(\mathrm{Ab}_{67-72} \mathrm{An}_{27-31} \mathrm{Or}_{02}\right)$ that overlap with those of plagioclase in the matrix. No compositional differences have been observed between K-feldspar porphyroclasts ( $\left.\mathrm{Or}_{74-83} \mathrm{Ab}_{17-26} \mathrm{An}_{00-01}\right)$ and K-feldspar crystals in leucocratic bands $\left(\mathrm{Or}_{75-82} \mathrm{Ab}_{18-25} \mathrm{An}_{00-01}\right)$.

Compared to the investigated quartzo-feldspathic mylonites, biotite in the matrix of quartzofeldspathic metatexites shows clearly lower $X_{\mathrm{Mg}}(0.33-0.35), \mathrm{F}(0.39), \mathrm{Cl}(0.07)$ and, to lower extent, $\mathrm{Ti}$ content (0.42-0.49 apfu), whereas garnet is enriched in Alm and Sps components having a composition $\operatorname{Alm}_{77-78} \operatorname{Prp}_{11-13} \operatorname{Sps}_{07-09} \operatorname{Grs}_{03-04}$ (Bartoli, 2012; Bartoli et al., 2013c). These data are in accordance with a lower $\mathrm{T}$ of equilibration of metatexites with respect to the mylonites, in accordance with phase 
equilibria modeling (see below, and Bartoli et al., 2013c) and field and petrology data (see above; Acosta, 1998).

\section{Microstructural and chemical characterization of melt inclusions}

Here we describe MI found in the quartzo-feldspathic mylonite ALP13 and, at the end of this section, their compositional features are briefly compared with those described in Bartoli et al. (2013c) for MI in quartzo-feldspathic metatexites.

MI-bearing garnet crystals show angular to rounded shapes both in the mesocratic matrix and in leucocratic bands, and may contain clusters of several MI (Fig. 5). Melt inclusions clusters with a subspherical geometry may occur both at the core and towards the rim of garnet (Figs. 3f, 5a). More

rarely, clusters have a sigmoidal to spiral-like shape (Fig. 5b,c). Melt inclusions generally do not occur close to the large mineral inclusions, similarly to what has been observed in garnets from anatectic enclaves by Acosta-Vigil et al. (2007). Melt inclusions have isometric (regular) shapes and range from approximately 2 to $10 \mu \mathrm{m}$ in diameter. In transmitted light, most of the MI appear totally or partially dark-brownish (Fig. 6a), and contain a polycrystalline aggregate of birefringent crystals under crosspolarized light. Other MI are transparent in plane-polarized light (Fig. 6b) and contain a homogeneous isotropic phase, i.e. glass, often with an empty (no $\mathrm{H}_{2} \mathrm{O}$ and $\mathrm{CO}_{2}$ have been detected by Raman spectroscopy) shrinkage bubble (Fig. 6b). In some garnets, dark-brownish MI mantle fibrolite needles (Fig. 6c).

When MI are investigated under the SEM, they appear typically facetted, and often with a welldeveloped negative crystal shape (Figs. 7,8 ). In each cluster, MI show a variable degree of crystallization ranging from totally crystallized MI (nanogranitoids; Cesare et al., 2015) to glassy (i.e., crystal-free) MI (Figs. 6a, 7a). No systematic difference in diameter between crystallized and glassy MI is observed. Locally, decrepitation tails project from nanogranitoids into the surrounding host (Fig. 7b). 
Crystallized inclusions contain aggregates of quartz, K-feldspar, biotite, muscovite, plagioclase (often modal Kfs $>\mathrm{Pl}$ ) with equigranular, hypidiomorphic to allotriomorphic texture (Figs. 7b, 8). Crystal size ranges from hundreds of $\mathrm{nm}$ to a few $\mu \mathrm{m}$.

Previous microstructural and experimental studies on other migmatitic rocks (see Ferrero et al., 2012; Bartoli et al., 2013b) have found that, despite the different degree of crystallization, MI within the same cluster have similar melt compositions. Therefore, we assume that nanogranitoids in mylonites are likely to have similar compositions to the coexisting glassy inclusions. Electron microprobe analyses have been performed on 39 totally glassy MI from three different thin sections of sample ALP13. The composition of the trapped melt is leucogranitic $\left(\mathrm{SiO}_{2} \approx 76 \mathrm{wt} \%\right.$, $\mathrm{FeO}+\mathrm{MgO}+\mathrm{MnO}+\mathrm{TiO}_{2}<2 \mathrm{wt} \%$ ) and peraluminous $[\mathrm{ASI}=1.05-1.38 ; \mathrm{ASI}=\mathrm{mol}$. $\left.\mathrm{Al}_{2} \mathrm{O}_{3} /\left(\mathrm{CaO}+\mathrm{Na}_{2} \mathrm{O}+\mathrm{K}_{2} \mathrm{O}\right)\right]$ (Table 2). The average maficity value (atomic Fe+Mg, Villaros et al., 2009) is generally low, $<0.03$. The analyzed $\mathrm{MI}$ are highly variable in $\mathrm{Na}_{2} \mathrm{O}$ and $\mathrm{K}_{2} \mathrm{O}$ contents and, based on the $\mathrm{K} \#\left[=m o l . \mathrm{K}_{2} \mathrm{O} /\left(\mathrm{Na}_{2} \mathrm{O}+\mathrm{K}_{2} \mathrm{O}\right)\right]$, can be grouped into two types: type I MI are characterized by $\mathrm{K} \#$ $\geq 0.6\left(\mathrm{Na}_{2} \mathrm{O} / \mathrm{K}_{2} \mathrm{O}<0.5\right)$, whereas type II MI show $\mathrm{K} \# \leq 0.5\left(\mathrm{Na}_{2} \mathrm{O} / \mathrm{K}_{2} \mathrm{O}>0.6\right)$ (Table 1). From all the analyzed MI, only 8 (found in 2 garnets) correspond to the type II, whereas the rest (31) are type I MI (Table 2). No compositional differences are observed between MI in mesocratic and leucocratic portions. The average $\mathrm{H}_{2} \mathrm{O}$ content estimated by difference (i.e. 100-EMP totals) is slightly but consistently lower in type I MI (2.4 wt \%) with respect to type II MI (3.6 wt \%). In terms of CIPW normative values, all the analyzed melts are corundum-normative. In the normative Qtz-Ab-Or diagram, all MI plot in the Qtz field above the $5 \mathrm{kbar}_{2} \mathrm{O}$ Qtz- $\mathrm{Ab}$ and Qtz-Or haplogranite cotectic curves, and at some distance from the eutectic melt compositions (Fig. 9). Data from analyzed glassy MI define two different clusters according to their K\# (Fig. 9).

Interestingly, compositions of type II MI overlap those of analyzed both glassy and rehomogenized MI from the quartzo-feldspathic metatexites at the base of the migmatitic sequence (Fig. 9; see also 
Bartoli et al., 2013b). Glassy MI from metatexites, however, consistently show lower FeO ( 1.20 wt $\%)$ and higher concentrations of $\mathrm{H}_{2} \mathrm{O}(5.4-9.1 \mathrm{wt} \%)$ and higher $\mathrm{Na}_{2} / \mathrm{K}_{2} \mathrm{O}$ when compared to $\mathrm{MI}$ in mylonites (Bartoli et al., 2014, 2015), in agreement with the lower temperatures of melting in their host rocks $\left(\approx 700{ }^{\circ} \mathrm{C}\right.$; Bartoli et al., 2013c).

\section{Phase equilibria modelling}

Modeling the $P-T$ conditions of melting and entrapment of the MI requires considering the presence of graphite, implying the involvement of a graphite-saturated $\mathrm{COH}$ fluid. In such a system, the $\mathrm{H}_{2} \mathrm{O}$ activity is lowered below unity due to the presence of diluting carbonic species such as $\mathrm{CH}_{4}$ and/or $\mathrm{CO}_{2}$ (Connolly and Cesare, 1993). Consequently, dehydration and partial melting reactions adjust their position in the $P-T$ space to accommodate this change of $a_{\mathrm{H} 2 \mathrm{O}}$ (Thompson and Algor, 1977; Spear 1993). Under the assumption that the fluid in the rock is essentially produced by $\mathrm{H}_{2} \mathrm{O}$ release from phyllosilicates, the amount of $\mathrm{H}_{2}$ and $\mathrm{O}_{2}$ components in the fluid is constrained at a ratio 2:1. At this initial condition (i.e. $X_{\mathrm{O}}=1 / 3$ of Connolly, 1995), the fluid composition contains the maximum activity of $\mathrm{H}_{2} \mathrm{O}$ for a graphite-saturated $\mathrm{COH}$ fluid.

A phase diagram has been constructed for the mylonitic sample ALP13 collected from the mesocratic portion of the outcrop of Fig. 3 a and containing only a thin $(\approx 1 \mathrm{~cm})$ leucocratic band. Because the sample ALP13 displays a non-residual bulk rock composition that, in addition, is very similar to those of quartzo-feldspathic undeformed diatexites at the top of the migmatitic sequence and stromatic metatexites at the bottom of the migmatitic sequence (all corresponding to Ca-poor peraluminous greywackes; Table 1), we infer that the bulk composition used in this modeling is not affected by any significant gain or loss of melt. The model chemical system MnNCaKFMASHTOC was used with the bulk rock composition obtained from XRF analysis (see the upper left inset of Fig. 10a). The amount of $\mathrm{H}_{2} \mathrm{O}$ component involved in the calculation was assumed as the loss of ignition of 
XRF analysis and thus represents the $\mathrm{H}_{2} \mathrm{O}$ content available for equilibration of the observed mineral assemblage. The amount of $\mathrm{C}$ was estimated from the modal proportion of graphite in the rock.

Although the Mn content of this rock is low $(<0.1 \mathrm{wt} \%)$, MnO was included in the modeling due to its influence on the stability of garnet (Spear 1993; Tinkham et al., 2001). All calculations were done by the Gibbs energy minimization using the Perple_X software (Connolly, 2009) with the thermodynamic database of Holland and Powell (1998, as revised in 2003). We used the solution model of melt from White et al. (2007), of garnet from Holland and Powell (1998), of biotite from Tajčmanová et al. (2009), of white mica from Coggon and Holland (2002), of plagioclase from Newton et al. (1980) and of K-feldspar from Thompson and Hovis (1979). An ideal model was used to account for the solution of $\mathrm{Mn}$ in cordierite and ilmenite.

Based on the petrographic study, we deduce that the stable mineral assemblage associated with melt (i.e., MI) in the studied mylonites corresponds to the quadrivariant field $\mathrm{Grt}-\mathrm{Bt}-\mathrm{Sil}-\mathrm{Pl}-\mathrm{Kfs}-\mathrm{Qtz}-\mathrm{Gr}-$ Ilm-Liq- $\mathrm{COH}$ (where $\mathrm{COH}$ means graphite-saturated $\mathrm{COH}$ fluid) in the upper right corner of the phase diagram section (Fig. 10a). The relevant compositional isopleths for MI-bearing garnet cores $\left(X_{\mathrm{Mg}}=\right.$ $\left.0.21-0.24 ; X_{\mathrm{Grs}}=0.02-0.03 ; X_{\mathrm{Sps}}=0.02-0.03\right)$ cross consistently in this field at $\approx 820^{\circ} \mathrm{C}$ and $\approx 6 \mathrm{kbar}$ (Fig. 10b). Similar temperature conditions are found considering the $X_{\mathrm{Mg}}$ of biotite (0.44-0.49) within the mesocratic matrix (Fig. 10b). At the pressure of interest, i.e. 6 kbar, muscovite and biotite are totally consumed at $\approx 700$ and $\approx 840-850{ }^{\circ} \mathrm{C}$, respectively (Fig. 10a). After crossing the Liq-in curve $\left(\approx 700{ }^{\circ} \mathrm{C}\right)$ the modal proportion of melt and garnet increases, whereas that of biotite decreases (Fig. 10c). Rutile appears at $\mathrm{P} \geq 7-8 \mathrm{kbar}$. The $X_{\mathrm{Mg}}=0.17-0.20$ and $X_{\mathrm{Sps}}=0.03$ isopleths for garnet rim in contact with biotite $( \pm \mathrm{Pl}, \pm \mathrm{Qtz})$ would overlap at $\approx 800^{\circ} \mathrm{C}$ and $\approx 5 \mathrm{kbar}$ in the same quadrivariant field (Fig. 10b). However, the $X_{\mathrm{Mg}}$ of low-Ti biotite (0.47-0.53) does not match these conditions (see Section 7.2 for explanation). The proportion of grahite is nearly constant in the whole $P-T$ space $(\approx 0.13$ vol. $\%)$. The stability field of $\mathrm{COH}$ fluid is connected to another phase containing the $\mathrm{O}_{2}$ component, which 
is biotite (see Section 7.3). It is important to point out that the amount of peritectic garnet inferred at $P-$ $T$ conditions of interest from thermodynamic modeling (2-3 vol.\%; Fig. 10c) is not consistent with petrographic observations which suggest instead modal amounts of $\approx 5-10$ vol. $\%$. This is likely due to the detrimental effect of Ti on the modal proportions of some phases. Bartoli et al. (2013c) have shown that the involvement of $\mathrm{Ti}$ in the chemical system produces an unrealistic decrease of modal proportions of some key Ti-free minerals (i.e. garnet) that have already relatively low modal proportion in the rock. However, the investigated mylonites contain a small amount of biotite (i.e. these strongly deformed rocks reached temperatures close to the Bt-out line; Fig. 10). Because $\mathrm{TiO}_{2}$ plays a fundamental role in extending the stability field of biotite in $P-T$ space (Tajčmanová et al., 2009 and references therein), this component must be included in the phase equilibria modeling in order to obtain more realistic $P-T$ estimates. The proportion of melt predicted by the modeling at $820^{\circ} \mathrm{C}$ and $6 \mathrm{kbar}$ is $\approx 10-12$ vol.\%.

\section{Discussion}

\subsection{Mylonites as former diatexites}

The zonal arrangement of MI in garnet (Figs. 4, 5) indicates that they were trapped during host growth -i.e. they are primary MI (Roedder, 1984; Frezzotti, 2001). The investigated rocks are strongly deformed and, therefore, the classic microstructures indicating the former presence of melt, such as mineral pseudomorphs after melt films and pools (see Holness and Sawyer, 2008; Holness et al., 2011), are generally absent. Only rare crystallized pools of melt have survived in strain shadows (Fig. 3e). However, the presence of abundant primary MI sheltered by the host garnet, which is resistant to deformation, clearly indicates the former occurrence of melt in the investigated mylonites. The quartzofeldspathic mylonites represent, therefore, former migmatites. The leucocratic bands, showing a coarser grain size, mainly composed of a granitic assemblage of plagioclase, K-feldspar and quartz and 
containing some igneous microstructures such as euhedral minerals (Fig. 3j), likely represent former anatectic leucosomes. The occurrence of a slightly more albitic plagioclase in these leucocratic portions with respect to the mesocratic domains is consistent with their crystallization from a melt (e.g. Sawyer, 2001). We interpret that the quartzo-feldspathic mylonites represent former diatexites, based on the following observations and arguments: i) the similarity in bulk rock composition between these mylonites, the underlying quartzo-feldspathic diatexites, and stromatic metatexites at the bottom of the migmatitic sequence (Table 1); ii) their structural position above the diatexitic migmatites and at the contact between the migmatitic sequence and the peridotites (Fig. 2); iii) the presence of simply twinned K-feldspar porphyroclasts (Fig. 3d) resembling the large K-feldspar observed in the diatexites but absent in the metatexites (Acosta, 1998); iv) the abundance of leucocratic bands (30-50 vol.\%) likely representing former leucosomes (Fig. 3a); and v) the apparently continuous evolution in terms of petrography, mineral proportions and chemistry, and MI compositions across the migmatitic sequence (Sections 4 and 5).

In this perspective, however, it can be noted that the maximum amount of melt predicted by phase equilibria modeling, $\approx 10-12$ vol.\% (Fig. 10c), is neither enough to form a diatexite (i.e., a meltsupported structure) nor consistent with field observations suggesting $\approx 30-50$ vol. $\%$ of leucosomes (Fig. 3a; see also Acosta, 1998). In anatectic terranes, the passage from metatexite to diatexite migmatite is commonly transitional, and schollen diatexites are expected to form at relatively low to moderate melt fractions of $\approx 25$ vol. $\%$, and in some cases even at values as low as 0.16 (see Figure 1 in Sawyer, 2008). Assuming that the protolith of the studied mylonites is similar to that of quartzofeldspathic metatexites at the bottom of the migmatitic sequence (as field, bulk rock composition, mineral and MI data strongly suggest), and considering the difference in the amount of biotite between the stromatic metatexites (see Bartoli et al., 2013c) and the mylonite (Fig. 10c), mass-balance considerations indicate that $\approx 15-20$ vol. $\%$ of a $\mathrm{H}_{2} \mathrm{O}$-undersaturated melt should have been produced 
from the protolith of the mylonites $\left(\mathrm{H}_{2} \mathrm{O}\right.$ in the melt $\approx 3 \mathrm{wt} \%$ as suggested by MI). This indicates that the thermodynamic model may somehow underestimate the proportion of melt produced in the mylonites.

Two additional explanations for the difference in melt proportion predicted by thermodynamic models versus indicated by the volume of leucosomes, are the influx of a hydrous fluid enhancing melt production (White et al., 2005) or the infiltration of melt from external sources (Hasalová et al., 2008). Water-fluxed melting is not supported by different lines of evidence described in section 7.2 (see below). On the other hand, Tubía et al. (1997) have reported (though not documented) the intrusion of granitic melts into the mylonitic package, as roughtly concordant granite bodies parallel to $\mathrm{S}_{\mathrm{myl}}$. Summarizing, field, compositional and textural arguments support that mylonites represent strongly deformed former diatexites; the discrepancy between calculated and observed amount of melt can be ascribed in part to the limitations of thermodynamic modeling (see discussion in Section 7.3) and to the infiltration of an external melt.

\subsection{P-T estimates of melting and mylonitization close to the peridotites}

$P-T$ conditions at which the MI were trapped and, in turn, the quartzo-feldspathic mylonites previously melted, are constrained at $\approx 820^{\circ} \mathrm{C}$ and $\approx 6 \mathrm{kbar}$ (Fig. 10b) by the intersection among the relevant compositional isopleths for MI-bearing garnet cores. The presence of sillimanite as trapped phase within MI proves that peritectic garnet and melt were produced in the field of sillimanite, in agreement with petrographic observations and phase equilibria modelling. Biotite replacing garnet (Fig. 3g) likely represents the product of melt-consuming reactions (Kriegsman and Hensen, 1998). In particular, the concomitant decrease and increase of $X_{\mathrm{Mg}}$ in garnet rims and adjacent biotite grains, respectively, indicate the progress of retrograde Fe-Mg exchange by diffusion ("ReERs" of Kohn and Spear 2000) between garnet and biotite in mutual contact (Fig. 3g, h). Because their compositions have 
been modified by occurrence of ReERs, their isopleths cannot be used for inferring the retrograde path.

After anatexis, the investigated rocks were strongly deformed down to subsolidus conditions (phase $\mathrm{D}_{4}$ of Tubía, 1988). According to Stipp et al. (2002) who studied natural deformation microstructures of quartz over a temperature range of $\approx 500{ }^{\circ} \mathrm{C}$, the formation of chessboard subgrains (Fig. 3h) may have occurred at $600-650{ }^{\circ} \mathrm{C}$. It is important to note that quartz deformation microstructures are not only temperature dependent, and additional factors (presence of fluid, strain rate and strain partitioning) may have an important effect (Mancktelow and Pennacchioni, 2004; Peternell et al., 2010). For example, the presence of $\mathrm{H}_{2} \mathrm{O}$ may decrease the estimated temperature of $\approx 100{ }^{\circ} \mathrm{C}$ (Little et al., 2013). The CPO (crystallographic preferred orientation) patterns of quartz from quartzo-feldspathic mylonites of the Ojén unit have been studied in detail by Tubía et al. (2013). Although they did not discuss the role of other variables in the development of quartz CPO (compare Stipp et al., 2002, and Peternell et al., 2010), they concluded that the observed quartz fabrics support that the mylonitization of the quartzo-feldspathic rocks occurred at HT $\left(>500-600{ }^{\circ} \mathrm{C}\right)$. Pressure, however, is not well constrained.

Because subsolidus penetrative deformation affected the entire rock, it is important to understand its role on the documented microstruture and composition of MI. Some nanogranitoids display diametrically opposite decrepitation tails (Fig. 7b), resembling the microstructures shown by fluid inclusions experimentally deformed by deviatoric stress (see Tarantola et al., 2010). Decrepitation cracks are usually filled with the same minerals observed within nanogranitoids, indicating that decrepitation took place before the beginning of melt crystallization (Ferrero et al., 2012).

Decrepitation may have induced fluid leakage from nanogranitoids (Cesare et al., 2011) and may have triggered crystallization by causing a pressure drop and, in turn, a drop in solubility within MI (Ferrero et al., 2012). However, the coexisting glassy MI do not show evidence of decrepitation, but rather a well-developed regular shape (Fig. 7a). The absence of microstructures indicative of decrepitation and 
overheating in glassy MI (cf. Figure 9 in Cesare et al., 2015) suggests that their EMP analyses reported in Table 2 can be considered as reliable compositions of the primary melt formed during the prograde melting of the host rocks.

\subsection{Considerations on the thermodynamic modeling of anatexis}

Phase equilibria modeling predicts that after crossing the solidus and with increasing temperature, the modal proportions of melt and garnet increase whereas the amount of biotite decreases (Fig. 10c). This indicates that partial melting occurred by a continuous melting reaction consuming biotite up to the Bt-out curve (Fig. 10) and also supports the peritectic nature of MI-bearing garnet. An intriguing aspect of our phase equilibria modeling is that a small amount $(\leq 0.01 \mathrm{vol} . \%)$ of $\mathrm{COH}$ fluid is present as long as biotite is stable above the solidus, and disappears in Bt-free assemblages (Fig. 10a). Such a pattern on the stability of $\mathrm{COH}$ fluids is due to an artifact of the modeling under the imposed bulk chemical constraints. In fact, since the $\mathrm{O}_{2}$ component is involved in the thermodynamic calculations, and since biotite is allowed to contain 10-15\% of iron as $\mathrm{Fe}^{3+}$ (Tajčmanová et al., 2009), in order to conserve mass Perple_X removes from the fluid phase the amount of oxygen required for the $\mathrm{Fe}_{2} \mathrm{O}_{3}$ component of biotite, leading to the attainment of the general conditions $X_{\mathrm{O}}<1 / 3-$ i.e. an imperceptible amount of a $\mathrm{CH}_{4}$-rich fluid $(\leq 0.01$ vol.\%) is forced to be present in Bt-bearing supersolidus assemblages. These conditions persist until biotite is totally consumed. At this point, since the melt model used does not account for the solubility of carbonic species, and since biotite is the only carrier of $\mathrm{Fe}^{3+}$ in the phase equilibria modeling, $X_{\mathrm{O}}$ returns to the input value of $1 / 3$, maximizing the amount of $\mathrm{H}_{2} \mathrm{O}$ dissolved in the melt and resulting in the consumption of the all free $\mathrm{H}_{2} \mathrm{O}$ available in the system and in the precipitation of a small amount of graphite. Although such a process may seem petrologically tenable, the presence of a $\mathrm{CH}_{4}$-rich fluid predicted by this modeling is clearly in contrast with the common occurrence of $\mathrm{CO}_{2}$-rich fluids in high-grade graphitic metamorphic terranes (e.g., 
Touret, 2009; Hollister, 1988; Cesare et al., 2007; Ferrero et al., 2011; La Madrid et al., 2014; Santosh and Omori, 2008). On the contrary, $\mathrm{CH}_{4}$ has been detected in a very few cases (e.g., Lamb et al., 1991). There are, however, independent petrologic lines of evidence suggesting that partial melting of the investigated rocks largely occurred in the absence of a fluid phase. They include: i) the $\mathrm{H}_{2} \mathrm{O}$ content of melt, estimated by difference from the EMP analyses of the glassy MI, is very close to the values predicted for $\mathrm{H}_{2} \mathrm{O}$-undersaturated melting at $\approx 820{ }^{\circ} \mathrm{C}$ and $\approx 6 \mathrm{kbar}(\approx 4 \mathrm{wt} \%$; Holtz et al., 2001); ii) the average ASI of the investigated MI is 1.20 , and corresponds to the value predicted by equilibrium experiments for $\mathrm{H}_{2} \mathrm{O}$-undersaturated melts derived from fluid-absent incongruent melting of biotite (Acosta-Vigil et al., 2003); iii) no primary fluid inclusions were found coexisting with the MI in the investigated rocks; iv) the lack of $\mathrm{Na}$ - and Ca-rich melts typically produced by $\mathrm{H}_{2} \mathrm{O}$-fluxed melting of metasedimentary rocks (Weinberg and Hasalová, 2015). For example, MI showing tonalitictrondhjemitic-granodioritic compositions with $\mathrm{H}_{2} \mathrm{O}$ contents between $\approx 8$ and $\approx 15 \mathrm{wt} \%$, and produced by $\mathrm{H}_{2} \mathrm{O}$-present melting have been recently documented in migmatites at the base of the Greater Himalayan Sequence (Himalaya, Nepal) and in the Jubrique sequence (Betic Cordillera, Spain) (Carosi et al., 2015; Acosta-Vigil et al., 2016). We therefore conclude that the extent melt + fluid field in Fig. 10a has been overestimated by the thermodynamic modeling.

Owing to the above problems in the modeling and in order to verify the reliability of the $P-T$ estimates obtained in the C-bearing system, a new $P-T$ section for the former diatexite of Fig. 10a has been calculated in a C-free system (Fig. 11). The displacement of Ms- and Bt-out curves is negligible and the phase assemblage Grt-Bt-Sil-Pl-Kfs-Qtz-Ilm-Liq observed in the sample still corresponds to the quadrivariant field in the upper right corner of the phase diagram section (Fig. 11). Instead, the shift of the solidus towards lower temperatures is significant at $\mathrm{P}<5 \mathrm{kbar}\left(\approx 60{ }^{\circ} \mathrm{C}\right.$ at $4 \mathrm{kbar}$ and $\approx 100{ }^{\circ} \mathrm{C}$ at 2 kbar; Fig. 11), as expected in non-graphitic systems (Cesare et al., 2003). The $P$ - $T$ conditions of equilibration during melting of the investigated rocks, however, do not differ in C-bearing and C-free 
systems $\left(\approx 820^{\circ} \mathrm{C}\right.$ and $\approx 6$ kbar; Fig. 11 and Fig. 1 in online supporting material). The most important difference between C-free and C-bearing systems is the extension of the $P-T$ area of coexistence of melt + fluid. In the $\mathrm{C}$-free phase diagram, melt and $\mathrm{H}_{2} \mathrm{O}$ coexist only on the $\mathrm{H}_{2} \mathrm{O}$-saturated solidus. After crossing the solidus, the system almost instantaneously evolves towards a fluid-absent state in which further melting proceeds by fluid-absent (i.e., hydrate-breakdown) melting reactions, supporting the inference that melting largely occurred in absence of a fluid phase.

In Figure 12, we compared the compositions of MI with the calculated melt composition obtained from the thermodynamic modeling at the $P-T$ conditions of interest. MI generally show higher $\mathrm{FeO}+\mathrm{MgO}$ and $\# \mathrm{~K}$, and lower $\mathrm{CaO}$ and $\mathrm{Al}_{2} \mathrm{O}_{3}$. The inconsistency between calculated and measured melt composition was already pointed out by Bartoli et al. (2013c) for stromatic metatexites from Ojén unit and by Grant (2009) and White et al. (2011) for experimentally remelted metapelites and metagreywackes, and has been ascribed to the current melt model which needs some improvements to reproduce properly natural processes (see discussion in Bartoli et al., 2013c). In the same figure, we also plotted experimental glasses produced by melting of metagreywackes at $810-850{ }^{\circ} \mathrm{C}, 5-7 \mathrm{kbar}$. Experimental melt compositions only partly overlap those of MI from Ojén metagreywackes and formed at similar $P-T$ conditions (Fig. 12). Because the composition of the source and conditions of anatexis play a primary control on melt chemistry (Neogi et al., 2014), only MI, rather than experiments and thermodynamic modeling, can make accessible the precise melt composition for the specific rock and the specific $P-T-X_{\mathrm{H} 2 \mathrm{O}}$ investigated (Bartoli et al., 2013, 2016; Cesare et al., 2015).

\subsection{P-T estimates and evolution of the Ojén unit: open questions}

Tubía (1988) and Tubía et al. (1997, 2013) have documented a structural continuity throughout Ojén unit, in terms of: (i) close orientation of foliations (strike from $\mathrm{N} 10^{\circ} \mathrm{E}$ to $\mathrm{N} 90^{\circ} \mathrm{E}$ and dip gently to moderately south), stretching lineations (trends varying from NNE-SSW to ENE-WSW) and fold axes 
parallel to the stretching lineation in the several rock types and at different structural levels; and (ii) similar evolution in time of the kinematics and localization of shear zones throughout the sequence of mylonites and migmatites, i.e. earlier shear zones are higher T, top-to-the ENE, and located at the contact with the peridotites, whereas later shear zones are lower T, top-to-the ENE and top-to-theNNW and located at or towards the contact between the anatectic sequence and schists.

Field observations indicate a progressive evolution in the morphological type of migmatite, from stromatic and fold-structured migmatites at the bottom of the sequence, to diatexite migmatites towards the middle-upper part of the section, where schollen, nebulitic and schlieric diatexitic migmatites have been described (Fig. 2; Acosta, 1998). Mylonites at the top of the sequence represent former diatexites (this study; see also Tubía, 1988; Acosta, 1998). Comparing quartzo-feldspathic rocks of similar bulk rock composition but varying metamorphic degree (Table 1), and in the frame of the phase equilibria modeling (section 6, Figs. 10, 11; see also Bartoli et al., 2013c), variations in mineral proportions, microstructures (see Section 4.1; compare Figs. 3 and 4), mineral and MI compositions (see Sections 4.2 and 5) and in melting reactions (from fluid-present, muscovite- and biotite-consuming to fluidabsent biotite dehydration melting; Bartoli et al., 2013c, 2015; this study) indicate an increase in T towards the top of the anatectic sequence (Fig. 13, and references in the caption).

Considering the metasedimentary crustal rocks, which constitute most of the sequence of Ojén (Fig. 2), it is clear also that $\mathrm{P}$ increases towards upper structural levels, (Fig. 13). Thus, a pressure of $\approx 8-9$ kbar reported for the mylonitic gneisses at the contact with the peridotites (Westerhof, 1975, 1977; Tubía et al., 1997) is in agreement with the occurrence of rutile trapped within MI in garnet found in these rocks (Bartoli et al., 2015), indicating the presence of anatectic melt in the rutile stability field. By contrast, lower pressures of 4.5-5 kbar at the bottom of the migmatitic sequence are reflected by the presence of peak MI-bearing Ilm crystals within the quartzo-feldspathic metatexites (Bartoli et al., 2015). This is consistent with an increase towards upper structural levels of the Grt/Crd modal ratio 
in rocks of similar bulk rock composition (Acosta, 1998). In addition, petrology and microstructures also indicate that after reaching the peak $P-T$ conditions, crustal rocks both at the contact with the peridotite and at the bottom of the migmatitic sequence experienced a decompression path (Fig. 13). This is clearly indicated, on the one hand, by formation of cordierite after garnet in pelitic granulites and previously reported decompression $P-T$ paths for mylonites and amphibolites/eclogites (Tubía et al., 1997); and, on the other hand, by the presence of cordierite-bearing neosomes obliterating the main foliation in the stromatic metatexites and postdating formation of garnet -bearing leucosomes (Figs. 2, 4, Section 4.1; see Acosta, 1998). The distribution and evolution of the $P$ - $T$ conditions documented at the different levels of the Ojén unit is difficult to explain considering a metamorphic continuity throughout the sequence and current petrogenetic models associated with the emplacement of a hot peridotite slab during continental subduction (Tubía et al., 1997, 2013; Mazzoli and Martín-Algarra, 2011, 2014).

Another important problem is that pressures $\geq 15 \mathrm{Kbar}$ recorded in eclogitic boudins at the base of the anatectic sequence (Tubía and Gil-Ibarguchi, 1991) contrast with both the much lower values recorded in their host metatexites (Fig. 2), and the upward increase in P shown by rocks in the crustal sequence (Fig. 13). These mafic rocks form rounded- to lenticular-shaped, cm-to-dm, or even 100-m thick, bodies parallel to the main foliation (Tubía, 1998), and their presence has been used by Tubía et al. (1997, 2013) and Mazzoli and Martín-Algarra $(2011,2014)$ to argue that the Ojén unit represents a coherent high-P portion of an Alpine continental subduction system. The presence of pods, boudins and lenses of eclogites within host metasedimentary rocks equilibrated at lower $P-T$ conditions is a common occurrence in orogenic belts worldwide (e.g. Carswell, 1990). These eclogite lenses have been explained either as (i) foreign tectonic slices brought together with the crustal rocks late in their metamorphic evolution, or (ii) rocks that, having been assembled together with the crustal rocks early and having experienced the same tectonometamorphic evolution, can record earlier metamorphic stages 
that are erased in their crustal hosts. In the latter case, although lower than in eclogites, pressures recorded in the metasediments are generally high as well ( $\geq 15-20 \mathrm{kbar}$; Li et al., 2015).

In the case of the Ojén unit, the presence of eclogite relicts, together with the decompression paths recorded by the crustal rocks (Fig. 13), might suggest that maximum pressures recorded in the crustal rocks represent retrograde pressures at which rocks equilibrated at some point during a decompression path from HP peak values (see Tubía et al., 1997). Several lines of evidence, however, are not in accordance this hypothesis. (1) Pressures exceeding 9 kbar have never been reported in the Ojén metasedimentary sequence, particularly close to the eclogite lenses (Fig. 13). (2) Metatexites are Capoor, Si-rich peraluminous metagreywacke (Table 1), very similar in composition to peraluminous granites, for which phase equilibria modeling and petrographic observations indicate mineral associations made of Ca-rich Grt+Ky+Rt at the $P-T$ recorded in the eclogites of Ojén (e.g., Tajčmanová et al., 2006; O’Brien, 2008; Massonne, 2009; Nahodilová et al., 2011). These minerals have never been described or reported in these rocks, whereas HP metagranitic rocks (i.e., felsic granulites) that experienced decompression down to 4-5 kbar and subsequent re-equilibration commonly preserve relics of the original HP mineral assemblage (e.g., Liu and Zhong, 1997; O’Brien and Rotzler, 2003; Tajčmanová et al., 2011). (3) The host metatexites have been well characterized in terms of petrography, petrology and $P-T$ conditions (Acosta, 1998; Bartoli, 2012; Bartoli et al., 2013b, c; this work), and all these detailed studies indicate that mineralogy and microstructures in these rocks correspond to those generated during the prograde history and at peak conditions, and not to retrograde associations after HP conditions. (4) Melt inclusions in garnet of rocks from the migmatitic sequence where trapped during prograde melting reactions, and there is a systematic evolution in the composition of the MI from the metatexites to the mylonites (Bartoli et al., 2015; this work), which is in accordance with the prograde $P-T$ history inferred from mineralogy, microstructures and comparison with phase equilibria modeling. In addition, in metatexites close to mafic boudins zircon overgrowths, interpreted 
to have crystallized from anatectic melts, have been dated at 290 Ma (sample NDA7 in SánchezRodríguez, 1998), whereas the eclogite protolith formed at ₹184 Ma (Sánchez-Rodríguez, 1998; Sánchez-Rodríguez and Gebauer, 2000).

Because Tubía et al. (2013) have described late metamorphic mylonitic bands close to the amphibolite/eclogite lenses, from all the above considerations we suggest that the high-P mafic rocks and low-P migmatites may have been assembled together in the crustal footwall after their peak metamorphism. Similarly, Štípská et al. (2008) demonstrated that the contrasting peak pressures of eclogite lenses and host migmatites from Bohemian Massif (Czech Republic) are the result of the tectonic mixing of rocks originally coming from different depths, rather than the exhumation of a coherent HP terrane affected by heterogeneous retrogression.

Additional problems in the area relate to the available $P-T$ data, showing a large variability and several inconsistencies such as: i) $P-T$ paths that cross each other at lower $\mathrm{P}$, e.g. eclogites and pelitic granulites, (ii) peak $P$ - $T$ values in pelitic granulites being $\approx 50-100{ }^{\circ} \mathrm{C}$ lower and $2-3$ kbar higher with respect to those in the underlying quartzo-feldspathic mylonites, and iii) $P$ - $T$ estimates for schists that are similar to, or higher than, those for the overlying migmatitic metatexites (Fig. 13). All these considerations raise doubts about the reliability of several of the thermobarometric estimates currently available in the literature for these rocks.

\section{Regional implications}

Most of the previous models have explained the tectono-metamorphic evolution of the Ojén and Guadaiza units as due to the oblique subduction of a continental margin in a transpressional setting in the early Miocene (i.e., the emplacement of Ronda peridotites occurred during continental subduction as a result of oblique plate convergence; Tubía et al., 1997, 2013; Mazzoli and Martín-Algarra, 2011, 2014). Accordingly, Ojén would have been subducted to deeper levels ( $\geq 50 \mathrm{Km}$ ) beneath the 
subcontinental mantle represented today by the Ronda peridotites, acquiring the high pressure metamorphic stage recorded in the eclogites. Conversely, the Guadaiza unit would have remained at mid-to-low crustal level depths. Alternatively, taking into account the petrologic and geochronological constraints proposed by Esteban et al. (2008, 2011a) for the Guadaiza unit at Sierra Bermeja, Précigout et al. (2013) provided numerical results supporting the emplacement of Ronda peridotites in a back-arc basin during the earliest Miocene (see also Garrido et al., 2011).

This study on the Ojén unit has raised some important issues which are not easy to explain by some of these previously proposed models. Among them, i) the crustal footwall at Sierra Alpujata represents an inverted metamorphic sequence, not only in terms of temperature but also in pressure, and ii) the Ojén unit does not seem to represent a coherent high-pressure portion of a continental subduction system. Regarding the generation and preservation of the inverted temperature gradients of the Ojén unit, Tubía et al. (1997) called for a combination of high temperatures in the overlying peridotites and rapid exhumation, as argued for many metamorphic soles of ophiolites. However, this model is rather general and does not provide a detailed explanation of the occurrence of lower peak pressure values towards the bottom of the sequence. Moreover, a very recent study of the Guadaiza unit has shown that a rather large portion of this unit records Variscan or older mineral assemblages and structures (AcostaVigil et al., 2014). Recent advances in the thermomechanical modeling (Moulas et al., 2014;

Tajčmanová et al., 2015) documenting the pressure build-up in and around bodies with a high viscous contrast, such as peridotites and migmatites studied here, might explain the pressure variation towards the top of the sequence. In addition, the zone of high strain rate may result in temperature increase due to viscous heating (e.g. Schmalholz and Podladchikov, 2013).

It follows that we are still far from understanding the origin, and geodynamic implications, of the tectono-metamorphic evolution of the western Alpujárride units, and particularly those located beneath the Ronda peridotite slab. In order to constrain the timing and mechanism of the crustal 
emplacement of the Ronda peridotites, future research on crustal rocks of the western Alpujárrides should focus on detailed petrological and geochronological studies of individual rock types within these crustal sequences, with particular emphases on those techniques that permit establishing a clear link between $P$ - $T$ conditions and ages.

\section{Acknowledgements}

This research benefitted from funding from the Italian Ministry of Education, University, Research (Progetto SIR RBSI14Y7PF to OB and grant PRIN 2010TT22SC to BC), from Padova University (Progetti per Giovani Studiosi 2013 to OB and Progetto di Ateneo CPDA107188/10 to BC), from Società Italiana di Mineralogia e Petrologia (grant for a research stay abroad to OB), from the Ministerio de Ciencia e Innovación of Spain (grant CGL2007-62992 and a Ramón y Cajal research contract to AAV), from MADE-IN-EARTH ERC starting grant (n. 335577) to LT and from the U.S. National Science Foundation (Grant No. EAR-1019770) to RJB. The research leading to these results has received funding from the European Commission, Seventh Framework Programme, under Grant Agreement $\mathrm{n}^{\circ} 600376$. We are grateful to $\mathrm{F}$. Rossetti and an anonymous reviewer for constructive comments. We also thank A Risplendente (Milan University) for assistance during EMP analyses, A. Cavallo (INGV, Rome) for help with SEM observations and S. McCartney (ICTAS, Virginia Tech) for assistance during elemental mapping. J.A.D. Connolly and G. Pennacchioni are also acknowledged for their helpful discussion on phase equilibria modeling and quartz microstructures, respectively.

\section{References}

Acosta, A., 1998. Estudio de los fenómenos de fusión cortical y generación de granitoides asociados a las peridotitas de Ronda. Unpublished PhD Thesis, Universidad de Granada, p. 305.

Acosta-Vigil, A., Buick, I., Hermann, J., Cesare, B., Rubatto, D., London, D., Morgan VI, G.B., 2010. Mechanisms of crustal anatexis: a geochemical study of partially melted metapelitic enclaves and host dacite, SE Spain. Journal of Petrology 51, 785-821.

Acosta-Vigil, A., Cesare, B., London, D., Morgan, G.B. VI, 2007. Microstructures and composition of melt inclusions in a crustal anatectic environment, represented by metapelitic enclaves within El Hoyazo dacites, SE Spain. Chemical Geology 235, 450-465.

Acosta-Vigil, A., London, D., Morgan VI, G.B., Dewers, T.A., 2003. Solubility of excess alumina in hydrous granitic melts in equilibrium with peraluminous minerals at $700-800{ }^{\circ} \mathrm{C}$ and $200 \mathrm{MPa}$, and applications of the aluminium saturation index. Contributions Mineralogy Petrology 146, 100-119.

Acosta-Vigil, A., Pereira, M.D., Shaw, D.M., London, D., 2001. Contrasting behaviour of boron during crustal anatexis. Lithos 56, 15-31.

Acosta-Vigil, A., Rubatto, D., Bartoli, O., Cesare, B., Meli, S., Pedrera, A., Azor, A., Tajc $\square$ manová, L., 2014. Age of anatexis in the crustal footwall of the Ronda peridotites, S Spain. Lithos 210-211, $147-167$.

Acosta-Vigil, A., Barich, A., Bartoli, O., Garrido, C.J., Cesare, B., Remusat, L., Poli, S., Raepsaet, C., 2016. The composition of nanogranitoids in migmatites overlaying the Ronda peridotites (Betic Cordillera, S Spain): the anatectic history of a polymetamorphic basement. Contributions to 
Mineralogy and Petrology 171:24.

Barich, A., Acosta-Vigil, A., Garrido, C.J., Cesare, B., Tajc $\square$ manová, L., Bartoli O., 2014. Microstructures and petrology of melt inclusions in the anatectic sequence of Jubrique (Betic Cordillera, S Spain): Implications for crustal anatexis. Lithos, 206-207, 303-320.

Bartoli, O., 2012. When the continental crust melts: a combined study of melt inclusions and classical petrology on the Ronda migmatites. Unpublished PhD Thesis, Università degli Studi di Parma, 128 pp.

Bartoli, O., Cesare, B., Poli, S., Acosta-Vigil, A., Esposito, R., Turina, A., Bodnar, R.J., Angel, R.J., Hunter, J., 2013a. Nanogranite inclusions in migmatitic garnet: behavior during piston cylinder remelting experiments. Geofluids 13, 405-420.

Bartoli, O., Cesare, B., Poli, S., Bodnar, R.J., Acosta-Vigil, A., Frezzotti, M.L., Meli, S., 2013b. Recovering the composition of melt and the fluid regime at the onset of crustal anatexis and S-type granite formation. Geology 41, 115-118.

Bartoli, O., Tajc $\square$ manová, L., Cesare, B., Acosta-Vigil, A., 2013c. Phase equilibria constraints on melting of stromatic migmatites from Ronda (S. Spain): insights on the formation of peritectic garnet. Journal of Metamorphic Geology 31, 775-789.

Bartoli, O., Cesare, B., Remusat, L., Acosta-Vigil, A., Poli, S., 2014. The $\mathrm{H}_{2} \mathrm{O}$ content of granite embryos. Earth and Planetary Science Letters 395, 281-290.

Bartoli, O., Acosta-Vigil, A., Cesare, B., 2015. High-temperature metamorphism and crustal melting: working with melt inclusions. Periodico di Mineralogia84, 3B, 591-614..

Bartoli, O., Acosta-Vigil, A., Ferrero, S., Cesare, B., 2016. Granitoid magmas preserved as melt inclusions in high-grade metamorphic rocks. American Mineralogist doi:10.2138/am-20165541CCBYNCND

Becker, A., Holtz, F., and Johannes, W., 1998. Liquidus temperatures and phase compositions in the system Qz-Ab-Or at 5 kbar and very low water activities. Contributions to Mineralogy and Petrology 130, 213-224.

Carswell, D.A., 1990. Eclogites and eclogite facies: definitions and classifications. In: Carswell, D.A. (Ed.), Eclogite Facies Rocks. Blackie and Son Ltd, New York, 1-13.

Carosi, R., Montomoli, C., Langone, A., Turina, A., Cesare, B., Iaccarino, S., Fascioli, L., Visonà, D., Ronchi, A., Man Rai, S., 2015. Eocene partial melting recorded in peritectic garnets from kyanitegneiss, Greater Himalayan Sequence, central Nepal. In: Mukherjee, S., Carosi, R., van der Beek, P. A., Mukherjee, B. K. \& Robinson, D. M. (Eds.), Tectonics of the Himalaya. Geological Society, London, Special Publications 412, pp. 111-129.

Cesare, B., Acosta-Vigil, A., Ferrero, S., Bartoli, O., 2011. Melt Inclusions in migmatites and granulites. In: Forster, M.A., Fitz Gerald, J.D. (Eds.), The Science of Microstructure - Part II. Journal of Virtual Explorer, (ISSN 1441-8142) 38, paper 2, Electronic edition.

Cesare, B., Acosta-Vigil, A., Bartoli, O., Ferrero, S., 2015. What can we learn from melt inclusions in migmatites and granulites?. Lithos 239, 186-216.

Cesare, B., Ferrero, S., Salvioli-Mariani, E., Pedron, D., Cavallo, A., 2009. Nanogranite and glassy inclusions: the anatectic melt in migmatites and granulites. Geology 37 627-630.

Cesare, B., Maineri, C., Baron Toaldo, A., Pedron, D. \& Acosta-Vigil, A., 2007. Immiscibility between carbonic fluids and granitic melts during crustal anatexis: a fluid and melt inclu- sion study in the enclaves of the Neogene Volcanic Province of SE Spain. Chemical Geology 237, 433-449.

Cesare, B., Marchesi, C., Hermann, J., Gomez-Pugnaire, M.T., 2003. Primary melt inclusions in andalusite from anatectic graphitic metapelites: implications for the position of the $\mathrm{Al}_{2} \mathrm{SiO} 5$ triple point. Geology 31, 573-576. 
Coggon, R., Holland, T.J.B., 2002. Mixing properties of phengitic micas and revised garnet-phengite thermobarometers. Journal of Metamorphic Geology 20, 683-696.

Connolly, J.A.D., 1995. Phase diagrams for graphitic rocks. Contributions to Mineralogy and Petrology 119, 94-116.

Connolly, J.A.D., 2009. The geodynamic equation of state: what and how. Geochemistry, Geophysics, Geosystems 10, Q10014.

Connolly, J.A.D., Cesare, B., 1993. C-O-H-S fluid composition and oxygen fugacity in graphitic metapelites. Journal of Metamorphic Geology 11, 379-388.

Cuevas, J., Esteban, J.J., Tubía, J.M., 2006. Tectonic implications of the granite dyke swarm in the Ronda peridotites (Betic Cordilleras, Southern Spain). Journal of the Geological Society 163, 631640.

Dewey, J.F., Helman, M.L., Turco, E., Hutton, D.H.W., Knott, S.D., 1989. Kinematics of the Western Mediterranean. In: Coward, M.P., Dietrich, D., Park, R.G. (Eds.), Alpine Tectonics. Special Publication, Geological Society of London, pp. 265-283.

Esteban, J.J., Cuevas, J., Vegas, N., Tubía, J.M., 2008. Deformation and kinematics in a melt-bearing shear zone from the Western Betic Cordilleras (Southern Spain). Journal of Structural Geology 30, 380-393.

Esteban, J.J., Cuevas, J., Tubía, J.M., Sergeev, S., Larionov, A., 2011a. A revised Aquitanian age for the emplacement of the Ronda peridotites (Betic Cordilleras, southern Spain). Geological Magazine $148,183-187$.

Esteban, J.J., Tubía, J.M., Cuevas, J., Vegas, N., Sergeev, S., Larionov, A., 2011b. Peri-Gondwanan provenance of pre- Triassic metamorphic sequences in the western Alpujarride nappes (Betic Cordillera, southern Spain). Gondwana Research 20, 443-449.

Ferrero, S., Bodnar, R.J., Cesare, B., Viti, C., 2011. Reequilibration of primary fluid inclusions in peritectic garnet from metapelitic enclaves, El Hoyazo, Spain. Lithos, 124, 117-131.

Ferrero, S., Bartoli, O., Cesare, B., Salvioli-Mariani, E., Acosta-Vigil, A., Cavallo, A., Groppo, C., Battiston, S., 2012. Microstructures of melt inclusions in anatectic metasedimentary rocks. Journal of Metamorphic Geology 30, 303-322.

Frezzotti, M.L., 2001. Silicate melt inclusions in magmatic rocks: applications to petrology. Lithos 55, 273-99.

Frezzotti, M.L., Ferrando, S., 2015. The chemical behavior of fluids released during deep subduction based on fluid inclusions. American Mineralogist 100, 352-377.

Garrido, C.J., Gueydan, F., Booth-Rea, G., Precigout, J., Hidas, K., Padron-Navarta, J.A., Marchesi, C. 2011. Garnet lherzolite and garnet- spinel mylonite in the Ronda peridotite: vestiges of Oligocene backarc mantle lithospheric extension in the western Mediterranean. Geology 39, 927-930.

Grant, J.A., 2009. THERMOCALC and experimental modeling of melting of pelite, Morton Pass, Wyoming. Journal of Metamorphic Geology 27, 571-578.

Hasalová, P., Štípská, P., Powell, R., Schulmann, K., Janoušek, V., Lexa, O., 2008. Transforming mylonitic metagranite by open-system interactions during melt flow. Journal of Metamorphic Geology 26, 55-80.

Holland, T.J.B., Powell, R., 1998. An internally consistent thermodynamic data set for phases of petrological interest. Journal of Metamorphic Geology 16, 309-343.

Holland, T.J.B., Powell, R., 2003. Activity-composition rela- tions for phases in petrological calculations: an asymmetric multicomponent formulation. Contributions to Mineralogy and Petrology 145, 492-501.

Hollister, L.S., 1988. On the origin of $\mathrm{CO}_{2}$-rich fluid inclusions in migmatites. Journal of Metamorphic Geology 6, 467-474. 
Holness, M.B., Sawyer, E.W., 2008. On the pseudomorphing of melt-filled pores during the crystallization of migmatites. Journal of Petrology 49, 1343-1363.

Holness, M.B., Cesare, B., Sawyer, E.W., 2011. Melted rocks under the microscope: microstructures and their interpretation. Elements, 7, 245-250.

Holtz, F., Johannes, W., Tamic, N., Behrens, H., 2001. Maximum and minimum water contents of granitic melts gener- ated in the crust: a re-evaluation and implications. Lithos, 56, 1-14.

Johnson, T.E., White, R.W., Powell, R., 2008. Partial melting of metagreywacke: a calculated mineral equilibria study. Journal of Metamoprhic Geology 26, 837-853.

Kohn, M.J., Spear, F., 2000. Retrograde net transfer reaction insurance for pressure-temperature estimates. Geology 28/12, 1127-1130.

Kretz, R., 1983. Symbols for rock-forming minerals. American Mineralogist 68, 277-279.

Kriegsman, L.M., Hensen, B.J., 1998. Back reaction between restite and melt: Implications for geothermobarometry and pressure-temperature paths. Geology 26, 1111-1114.

Lamadrid, H.M., Lamb, W.M., Santosh, M., Bodnar, R.J., 2014. Raman spectroscopic characterization of $\mathrm{H}_{2} \mathrm{O}$ in $\mathrm{CO}_{2}$-rich fluid inclusions in granulite facies metamorphic rocks. Gondwana Research 26, 301-310.

Lamb, W.M., Brown, P.E., Valley, J.W., 1991. Fluid inclusions in Adirondack granulites: implications for the retrograde P-T path. Contributions to Mineralogy and Petrology 107, 472-483.

Li, J-L., Klemd, R., Gao, J., Jiang, T., Song, Y-H., 2015. A common high-pressure metamorphic evolution of interlayered eclogites and metasediments from the 'ultrahigh-pressure unit' of the Tianshan metamorphic belt in China. Lithos 226, 169-182.

Little, T.A., hacker, B.R., brownlee, S.J., Seward, G., 2013. Microstructures and quartz latticepreferred orientations in the eclogite-bearing migmatitic gneisses of the D'Entrecasteaux Islands, Papua New Guinea. Geochemistry Geophysics Geosystems 14/6, doi:10.1002/ggge.20132.

Liu, Y., Zhong, D., 1997. Petrology of high-pressure granulites from the eastern Himalayan syntaxis. Journal of Metamorphic Geology 15. 451-466.

Loomis, T.P., 1972. Diapiric emplacement of the Ronda high-temperature ultramafic intrusion, southern Spain. Geological Society of America Bulletin 83, 2475-2496.

Lundeen, M.T., 1978. Emplacement of the Ronda peridotite, Sierra Bermeja, Spain. Geological Society of America Bulletin 89, 172-180.

Mancktelow, N.S., Pennacchioni, G., 2004. The influence of grain boundary fluids on the microstructure of quartz-feldspar mylonites. Journal of Structural Geology 26, 47-69.

Massonne, H.-J., 2009. Hydration, dehydration, and melting of metamorphosed granitic and dioritic rocks at high- and ultrahigh-pressure conditions. Earth and Planetary Science Letters 288, 244-254.

Massonne, H.-J., 2014. Wealth of P-T-t information in medium-high grade metapelites: example from the Jubrique Unit of the Betic Cordillera, S Spain. Lithos 208-209, 137-157.

Mazzoli, S., Martín Algarra, A., 2011. Deformation partitioning during transpressional emplacement of a 'mantle extrusion wedge': the Ronda peridotites, western Betic Cordillera, Spain. Journal of the Geological Society, London 168, 373-382.

Mazzoli, S., Martín Algarra, A., 2014. Comment on: "Localization of deformation and kinematic shift during the hot emplacement of the Ronda peridotites (Betic Cordilleras, southern Spain)" by J.M. Tubía, J. Cuevas, and J.J. Esteban, Journal of Structural Geology 50 (2013), 148-160. Journal of Structural Geology 60, 97-101.

Michard, A., Goffé, B., Bouybaouène, M.L., Saddiqi, O., 1997. Late Hercynian-Mesozoic thinning in the Alboran domain: metamorphic data from the northern Rif, Morocco. Terra Nova 9, 171-174.

Montel, J.M., Vielzeuf, D., 1997. Partial melting of metagreywackes, Part II. Compositions of minerals and melts. Contributions to Mineralogy and Petrology 128, 176-196. 
Morgan, G.B., London, D., 1996. Optimizing the electron microprobe analysis of hydrous alkali aluminosilicate glasses. American Mineralogist, 81 1176-1185.

Morgan, G.B., London, D., 2005. Effect of current density on the electron microprobe analysis of alkali aluminosilicate glasses. American Mineralogist 90, 1131-1138.

Moulas, E., Burg, J.P., Podladchikov, Y., 2014. Stress field associated with elliptical inclusions in a deforming matrix: mathematical model and implications for tectonic overpressure in the lithosphere. Tectonophysics 631, 37-49.

Nahodilová, R., Faryad, S.W., Dolejš, D., Tropper, P., Konzett, J., 2011. High-pressure partial melting and melt loss in felsic granulites in the Kutná Hora complex, Bohemian Massif (Czech Republic). Lithos 125, 641-658.

Navarro-Vilá, F., Tubía, J.M., 1983. Essai d'une nouvelle différenciation des Nappes Alpujárrides dans le secteur occidental des Cordillères Bétiques (Andalousie, Espagne). Comptes Rendus de l'Académie des Sciences Paris 296, 111-114.

Neogi, S., Bolton, E.W., Chakraborty, S., 2014. Timescales of disequilibrium melting in the crust: constraints from modelling the distribution of multiple trace elements and a case study from the Lesser Himalayan rocks of Sikkim. Contributions to Mineralogy and Petrology 168:1020.

Newton, R.C., Charlu, T.V.\& Kleppa, O.J., 1980. Thermo- chemistry of high structural state plagioclases. Geochimica et Cosmochimica Acta, 44, 933-941.

Obata, M., 1980. The Ronda peridotite: garnet-, spinel-, and plagioclase-lherzolite facies and the P-T trajectories of a high temperature mantle intrusion. Journal of Petrology, 21, 533-572.

O’Brien, P.J., 2008. Challenges in high-pressure granulite metamorphism in the era of pseudosections: reaction textures, compositional zoning and tectonic interpretation with examples from the Bohemian Massif. Journal of Metamorphic Geology 26, 235-251.

O’Brien, P.J., Rötzler, J., 2003. High-pressure granulites: formation, recovery of peak conditions and implications for tectonics. Journal of Metamorphic Geology 21, 3-20.

Patiño Douce, A.E., Beard, J.S., 1996. Effects of $\mathrm{P}, f\left(\mathrm{O}_{2}\right)$ and $\mathrm{Mg} / \mathrm{Fe}$ ratio on dehydration melting of model metagreywackes. Journal of Petrology 37, 999-1024.

Pattison, D.R.M., 1992. Stability of andalusite and sillimanite and the $\mathrm{Al}_{2} \mathrm{SiO}_{5}$ triple point, constraints from the Ballachulish aureole, Scotland. Journal of Geology 100, 423-446.

Peternell, M., Hasalová, P., Wilson, C.J.L., Piazolo, S., Schulmann, K., 2010. Evaluating quartz crystallographic preferred orientations and the role of deformation partitioning using EBSD and fabric analyser techniques. Journal of Structural Geology 32, 803-817.

Platt, J.P., Argles, T.W., Carter, A., Kelley, S.P., Whitehouse, M.J., Lonergan, L., 2003. Exhumation of the Ronda peridotite and its crustal envelope: Constraints from thermal modelling of a P-T-time array. Journal of the Geological Society of London 160, 655-676.

Platt, J.P., Behr, W.M., Johanesen, K., Williams, J.R., 2013. The Betic-Rif arc and its orogenic hinterland: A review. Annual Review of Earth and Planetary Sciences 41, 14.1-14.45.

Platt, J.P., and Vissers, R.L.M., 1989. Extensional collapse of thickened conti- nental lithosphere: A working hypothesis for the Alboran Sea and Gibraltar arc. Geology 17, 540-543.

Précigout, J., Gueydan, F., Garrido. C.J., Cogné, N., Booth-Rea, G., 2013. Deformation and exhumation of the Ronda peridotite (Spain). Tectonics 32, 1-15.

Priem, H.N.A., Boelrijk, N.A.I.M., Hebeda, E.H., Oen, I.S., Verdurmen, E.A.Th., Verschure, R.H., 1979. Isotopic dating of the emplacement of the ultramafic masses in the Serranía de Ronda, Southern Spain. Contributions to Mineralogy and Petrology 70, 103-109.

Roedder, E., 1984. Fluid inclusions. Mineralogical Society of America, Reviews in Mineralogy, 12 , 644.

Sánchez-Navas, A., García-Casco, A., Martín-Algarra, A., 2014. Pre-Alpine discordant granitic dikes 
in the metamorphic core of the Betic Cordillera: tectonic implications. Terra Nova 26/6, 477-486.

Sánchez-Rodríguez, L., 1998. Pre-Alpine and Alpine evolution of the Ronda Ultramafic Complex and its country-rocks (Betic chain, southern Spain): U-Pb SHRIMP zircon and fission-track dating. (PhD Thesis) ETH, Zürich, p. 170.

Sánchez-Rodríguez, L., Gebauer, D., 2000. Mesozoic formation of pyroxenites and gabbros in the Ronda area (southern Spain), followed by Early Miocene subduction metamorphism and emplacement into the middle crust: U-Pb sensitive high-resolution ion microprobe dating of zircon. Tectonophysics 316, 19-44.

Santosh, M., Omori, S., 2008. CO2 flushing: a plate tectonic perspective. Gondwana Research 13, 86102.

Sawyer, E.W., 2001. Melt segregation in the continental crust: distribution and movement of melt in anatectic rocks. Journal of Metamorphic Geology, 19, 291-309.

Sawyer, E.W., 2008. Atlas of migmatites. Mineralogical Association of Canada. The Canadian Mineralogist Special Publication 9, Quebec City.

Schmalholz, S.M., Podladchikov, Y.Y., 2013. Tectonic overpressure in weak crustal-scale shear zones and implications for the exhumation of high-pressure rocks. Geophysical Research Letters 40, 1984-1988.

Spear, F.S., 1993. Metamorphic Phase Equilibria and Pressure-Temperature-Time Paths. Mineralogical Society of America, Washington DC, 799 pp.

Stipp, M., Stünitz, H., heilbronner R., Schmid, S.M. 2002. The eastern Tonale fault zone: a 'natural laboratory' for crystal plastic deformation of quartz over a temperature range from 250 to $700{ }^{\circ} \mathrm{C}$. Journal of Structural Geology 24, 1861-1884.

Štípská, P., Schulmann, K., Powell, R., 2008. Contrasting metamorphic histories of lenses of highpressure rocks and host migmatites with a flat orogenic fabric (Bohemian Massif, Czech Republic): a result of tectonic mixing within horizontal crustal flow?. Journal of Metamorphic Geology 26, 623-646.

Tajčmanová, L., Abart, R., Neusser, G., Rhede, D., 2011. Growth of decompression plagioclase rims around metastable kyanite from high-pressure felsic granulites (Bohemian Massif). Journal of Metamorphic Geology, 29, 1003-1018.

Tajčmanová, L., Conolly, J.A.D., Cesare, B., 2009. A thermodynamic model for titanium and ferric iron solution in biotite. Journal of Metamorphic Geology 27, 153-165.

Tajčmanová, L., Konopásek, J., Schulmann, K., 2006. Thermal evolution of the orogenic lower crust during exhumation within a thickened Moldanubian root of the Variscan belt of Central Europe. Journal of Metamorphic Geology 24,119-134.

Tajčmanová, L., Vrijmoed, J. Moulas, E., 2015. Grain-scale pressure variations in metamorphic rocks: implications for the interpretation of petrographic observations. Lithos 216-217, 338-351.

Tarantola, A., Diamond, L.W., Stünitz, H., 2010. Modification of fluid inclusions in quartz by deviatoric stress I: experimentally induced changes in inclusion shapes and microstructures. Contributions to Mineralogy and Petrology 160, 825-843.

Thompson, A.B., Algor, J.R., 1977. Model systems for anatexis of pelitic rocks. I. Theory of melting reactions in the system $\mathrm{KAlO}_{2}-\mathrm{NaAlO}_{2}-\mathrm{Al}_{2} \mathrm{O}_{3}-\mathrm{SiO}_{2}-\mathrm{H}_{2} \mathrm{O}$. Contributions to Mineralogy and Petrology 63, 247-269.

Thompson, J.B., Hovis, G.L., 1979. Entropy of mixing in sanidine. American Mineralogist 64, 5765.

Tinkham, D.K., Zuluaga, C.A., Stowell, H.H., 2001. Metapelite phase equilibria modeling in MnNCKFMASH: the effect of variable $\mathrm{Al}_{2} \mathrm{O}_{3}$ and $\mathrm{MgO} /(\mathrm{MgO}+\mathrm{FeO})$ on mineral stability. Geological Materials Research 3, 1-42. 
Torres-Roldán, R.L., 1983. Fractionated melting of metapelite and further crystal-melt equillibria. The example of the Blanca Unit migmatite complex, north of Estepona (southern Spain). Tectonophysics 96, 95-123.

Touret, J.L.R., 2009. Mantle to lower-crust fluid/melt transfer through granulite metamorphism. Russian Geology and Geophysics 50, 1052-1062.

Tubía, J.M., 1988. Estructura de los Alpujárrides occidentales: cinemática y condiciones de emplazamiento de las peridotitas de Ronda. Publicaciones Especiales del Boletín Geológico y Minero de España. 99, p. 124.

Tubía, J.M., Gil-Ibarguchi, J.I., 1991. Eclogites of the Ojen nappe: a record of subduction in the Alpujarride complex (Betic Cordilleras, southern Spain). Journal of the Geological Society 148, 801-804.

Tubía, J.M., Cuevas, J., Gil-Ibarguchi, J.I., 1997. Sequential development of the metamorphic aureole beneath the Ronda peridotites and its bearing on the tectonic evolution of the Betic Cordillera. Tectonophysics 279, 227-252.

Tubía, J.M., Cuevas, J., Esteban, J.J., 2013. Localization of deformation and kinematics shift during the hot emplacement of the Ronda peridotites (Betic Cordilleras, southern Spain). Journal of Structural Geology 50, 148-160.

Villaros, A., Stevens, G., Moyen, J..F, Buick, I.S. 2009. The trace element compositions of S-type granites: evidence for disequilibrium melting and accessory phase entrainment in the source. Contributions to Mineralogy and Petrology 158, 543-61.

Weinberg, R.F., Hasalovà, P., 2015. Water-fluxed melting of the continental crust: a re- view. Lithos $212-215,158-188$.

Westerhof, A.B., 1975. Genesis of a magnetite ore near Marbella, Southern Spain: Formation by oxidation of silicates in polymetamorphic gedrite-bearing and other rocks. PhD Thesis, University of Amsterdam, G.U.A. papers of Geology 6, 216 pp.

Westerhof, A.B., 1977. On the contact relations of high-temperature peridotites in the Serrania de Ronda, southern Spain. Tectonophysics 39, 579-591.

Wilke, S., klahn, C., Bolte T., Almeev, R., Holtz, F., 2015. Experimental investigation of the effect of $\mathrm{Ca}, \mathrm{Fe}$ and $\mathrm{Ti}$ on cotectic compositions of the rhyolitic system. European Journal of Mineralogy 27/2, 147-159.

White, R.W., Pomoroy, N.E., Powell. R., 2005. An in situ metatexite-diatexite transition in upper amphibolite facies rocks from Broken Hill, Australia. Journal of Metamorphic Geology 23, 579602.

White, R.W., Powell, R., Holland, T.J.B., 2007. Progress relating to calculation of partial melting equilibria for metapelites. Journal of Metamorphic Geology 25, 511-527.

White, R.W., Stevens, G., Johnson, T.E., 2011. Is the crucible reproducible? Reconciling melting experiments with thermodynamic calculations. Elements 7, 241-246

Zeck, H.P., Monie', P., Villa, I., Hansen, B.T., 1992. Very high rates of cooling and uplift in the Alpine belt of the Betic Cordilleras, southern Spain. Geology, 20, 79-82.

\section{Captions}

Fig. 1. (a) Location map of the study area on the Iberian Peninsula in southern Spain. (b) Simplified geological map of the western sector of the Betic Cordillera (modified after Esteban et al., 2011b). (c) Geological map of the Sierra Alpujata massif. Blue and yellow stars show the location of the studied 
mylonites ( $\mathrm{N} 36^{\circ} 36 \square 31.9 \square$, W44ㅁ $\square 21.7 \square$ ) and of the stromatic metatexites investigated by Bartoli et al. (2013c), respectively.

Fig. 2. Schematic cross-section based on work of Tubía (1988) and Acosta (1998) of the crustal footwall of the Ronda peridotites at Sierra Alpujata showing the location of the studied mylonitic samples (blue star as in Figure 1). The photomicrographs $(4.2 \times 2.2 \mathrm{~mm})$ show the microstructural evolution of migmatites as a function of distance from the bottom of the Ronda peridotite slab. Red arrows show the location of peritectic Grt. Yellow lines show the traces of the main foliation defined by biotite and/or sillimanite folia.

Fig. 3. Outcrop views (a, b) and photomicrographs (c-l) of the investigated rocks. (a) Quartzofeldspathic mylonites outcropping at Sierra Alpujata with leucocratic bands (interpreted as former leucosomes) parallel to main foliation. Coin $=2 \mathrm{~cm}$. (b) Close-up of garnet-bearing leucosome (with tip of pen pointing to the garnet). (c) Mesocratic matrix showing fabric-forming sillimanite, biotite and ilmenite (Sil>>Bt>Ilm). White arrows: graphite lamellae. (d) K-feldspar porphyroclast showing simple twinning. (e) Quartz with irregular outlines containing euhedral Pl and Bt. This domain has probably crystallized from a pool of melt (see Holness et al., 2011). (f) Garnet shows embayment and replacement by Bt. Red dotted square: MI cluster. $(\mathrm{g}, \mathrm{h})$ Characteristic deformation microstructures of quartz formed by grain boundary migration recrystallization and showing cuspate-lobate boundaries and irregular subgrains (g) or approximately square (i.e., chessboard) subgrains (h). (k, l) Photomicrographs of two leucosomes. In (g) feldspars and quartz are deformed and elongated, and scattered in a fine-grained matrix, whereas in (h) there is a dense framework of euhedral feldspars (white arrows) touching along faces.

Fig. 4. Outcrop view (a) and photomicrographs (b, c) of the quartzo-feldspathic metatexites collected towards the bottom of the migmatitic sequence (see yellow star in Figure 2). (a) Small cordieritebearing leucogranitic patches obliterate the main foliation. (b) The main foliation is defined by abundant oriented biotite grains, and garnet occurs as small crystals. (c) Cordierite-bearing leucocratic domains have microstructures dominated by crystallization of the melt, such as quartz with a interstitial morphology (white asterisk) surrounding euhedral grains of feldspars (white arrows).

Fig. 5. Photomicrographs of the host garnets showing the different arrangements of MI clusters (red dotted lines). (a) MI cluster with a subspherically (equant) shape located near the garnet core. (b) MI cluster with a sigmoidal shape. (c) MI cluster with a spiral-like shape.

Fig. 6. (a) Cluster of crystallized (white arrows) and preserved glassy (red arrows) melt inclusions. (b) Glassy MI containing a shrinkage bubble (red arrow). (c) Crystallized MI with a Sil needle (white arrow) that is likely to have favored the entrapment of melt.

Fig. 7. SEM-BSE images of melt inclusions in garnet with the typical negative crystal shape. (a) Coexistence of nanogranitoids (white arrows) and preserved glassy MI (gray arrows) in the same cluster. (b) Fully crystallized inclusions (i.e. nanogranitoids). Black arrows: decrepitation cracks.

Fig. 8. Elemental EDS X-rays map of a nanogranitoid inclusion in mylonite ALP13.

Fig. 9. CIPW normative compositions of analyzed MI, shown on the Qtz-Ab-Or diagram (see text for 
details). Dashed lines: outline fields defined by the distributions of the retrieved compositions. Black dots: mean compositions. Compositions of MI from metatexites (gray area) are plotted for comparison (data from Bartoli et al., 2013b). Black triangle and lines show eutectic point and cotectic lines for the subaluminous haplogranite system at $0.5 \mathrm{GPa}$ and $\mathrm{a}_{\mathrm{H} 2 \mathrm{O}}=1$; black stars are eutectic points at $\mathrm{a}_{\mathrm{H} 2 \mathrm{O}}=0.6$ and 0.4 (Becker et al. 1998). The involvement of Fe, Ti and $\mathrm{Ca}$ moves eutectic points and cotectic curves toward more quartz-rich, albite-poor compositions (Wilke et al., 2015).

Fig. 10. (a) P-T section for mylonite ALP13calculated in MnNCaKFMASHTOC system. (b) Contours for grossular and spessartine components and $X_{\mathrm{Mg}}$ value of garnet, and for Ti content and $X_{\mathrm{Mg}}$ value of biotite. Yellow ellipse: inferred $P-T$ conditions for formation of MI-bearing garnet cores. (c) Isopleths of modal proportions of biotite, garnet and melt.

Fig. 11. $P-T$ section in the system MnNCaKFMASHT for the mylonite composition. Important curves in the C-bearing system (Figure 10) are superimposed: dotted yellow line for Ms-out curve, dotted blue line for Bt-out curve and dotted red line for Liq-in curve. The gray field reflects the region of melt + fluid coexistence in the C-bearing system. Yellow ellipse: inferred $P-T$ conditions for MI-bearing garnet cores (see Fig. 1 in supporting online material). 1) Bt-Crd-Pl-Kfs-Ilm-Qtz-H ${ }_{2} \mathrm{O}$; 2) Bt-Crd-PlKfs-Ilm-And-Qtz-H ${ }_{2} \mathrm{O}$; 3 ) Bt-Kfs-Crd-Pl-Qtz-Ilm-Sil- $\mathrm{H}_{2} \mathrm{O}$ 4) Bt-Pl-Kfs-Sil-Grt-Qtz-H ${ }_{2} \mathrm{O}$; 5) Bt-KfsCrd-Pl-Qtz-Ilm-Sil-Liq.

Fig. 12. $\mathrm{FeO}+\mathrm{MgO}$ vs. $\mathrm{CaO}$ and $\mathrm{FeO}+\mathrm{MgO}$ vs. $\mathrm{K} \#$ diagrams comparing compositions of melt inclusions, calculated melts and experimental glasses. $\mathrm{K} \#=m o l . \mathrm{K}_{2} \mathrm{O} /\left(\mathrm{Na}_{2} \mathrm{O}+\mathrm{K}_{2} \mathrm{O}\right)$. Light grey areas show the compositional domains corresponding to experimental melts produced by partial melting of metagreywackes at $810-850{ }^{\circ} \mathrm{C}, 5-7$ kbar (data from Patiño Douce and Beard, 1996; Montel and Vielzeuf, 1997). Note that these glasses show $\mathrm{CaO}$ content up to $1.5 \mathrm{wt} \%$; not shown in (a). See text for details.

Fig. 13. (a) Various $P-T$ estimates derived from different rocks in the crustal footwall of the Ronda peridotites at Sierra Alpujata (Ojén unit). $P-T$ conditions for the quartzo-feldspathic mylonite are from this study. T97 refers to Tubía et al. (1997), TI91 to Tubía and Gil-Ibarguchi (1991), W77 to Westerhof (1977), B13c to Bartoli et al. (2013c), P92 to Pattison (1992). Areas with continuous lines refer to P and/or T peak conditions for each rock type. Mylonitic gneisses described by Tubía et al. (1997) correspond to pelitic granulites of Figure 2 and Section 4.1. (b) Simplified section reported in Figure 2, showing the relative stratigraphic position of the rocks reported in (a). See text for explanation.

Tab. 1. Electron microprobe analyses (wt\%) of minerals from mylonite ALP13 and bulk rock composition of quartzo-feldspathic migmatites.

Tab. 2. Major element composition (wt $\%$ ) of glassy melt inclusions. Numbers in parentheses refer to $1 \sigma$ standard deviation. 


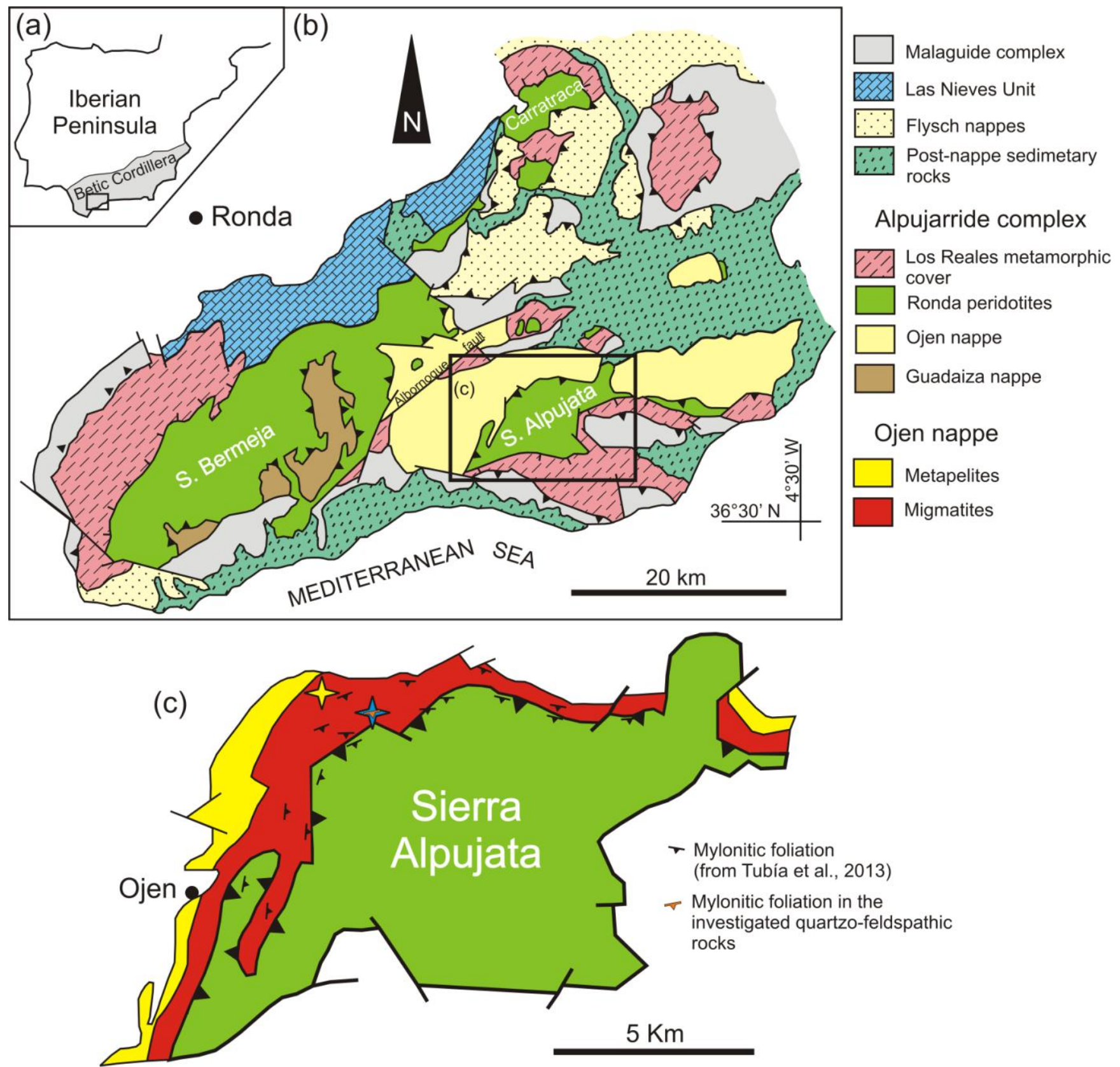

Figure 1 

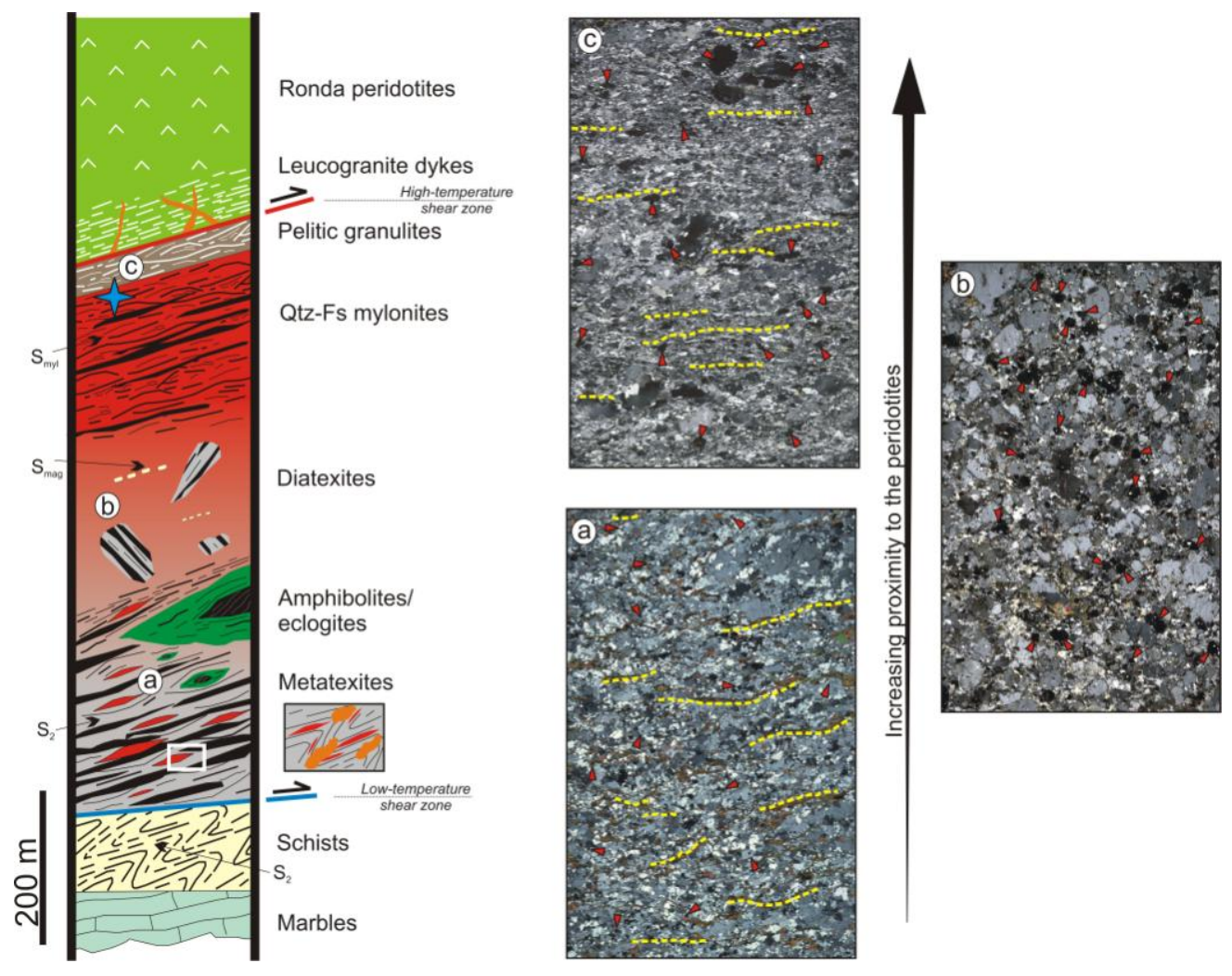

Figure 2 

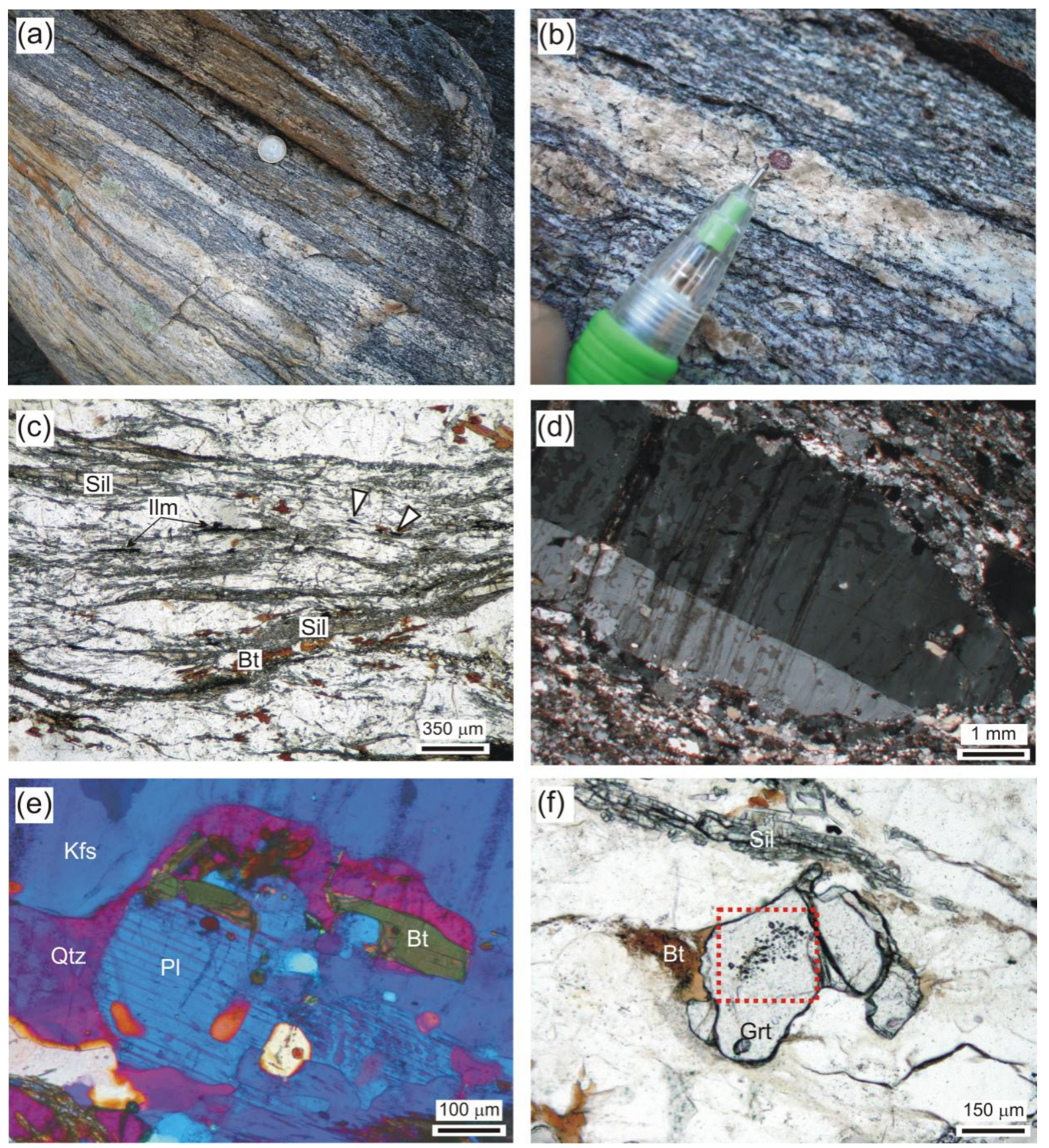

Figure 3a 

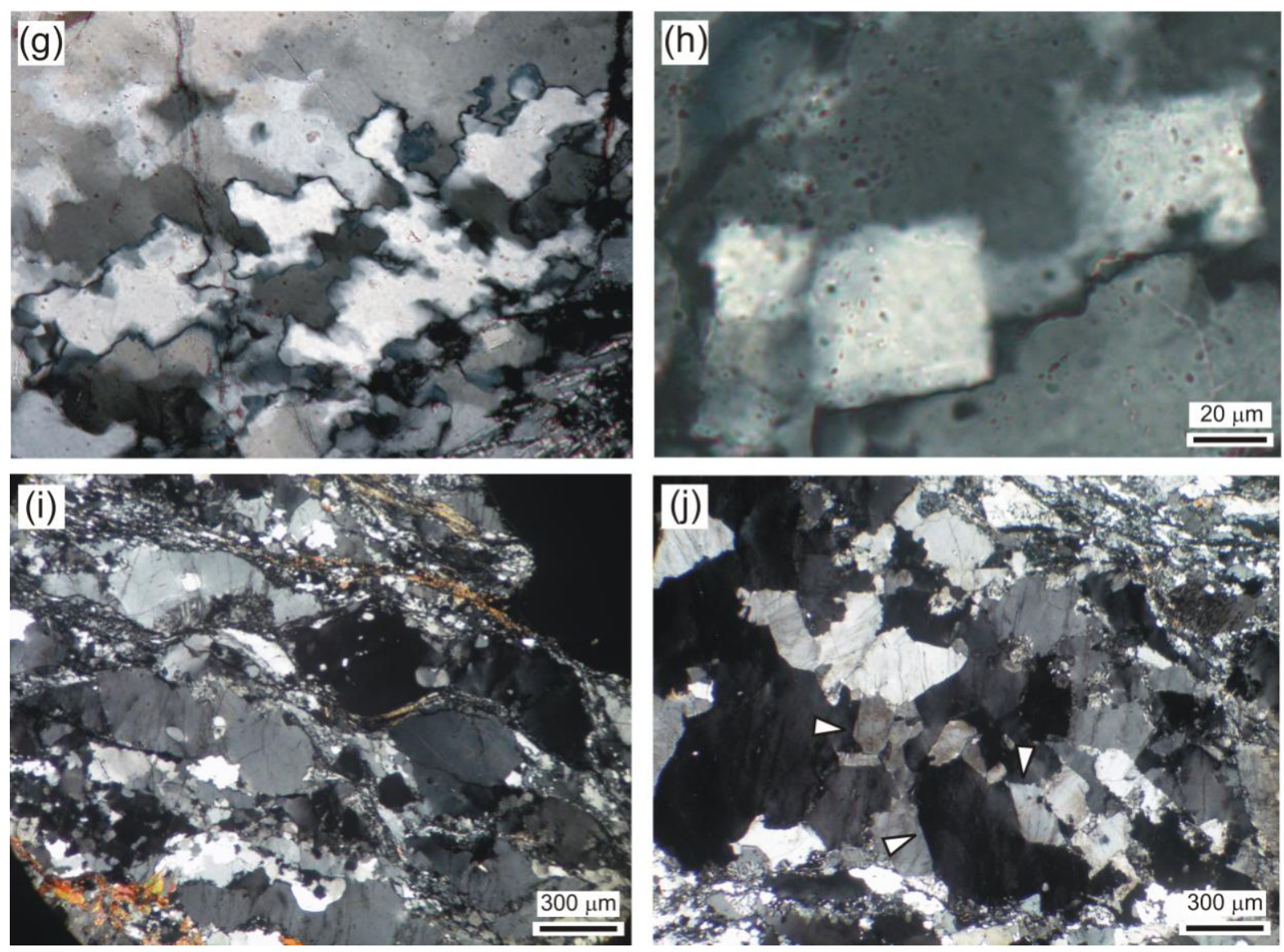

Figure $3 b$ 

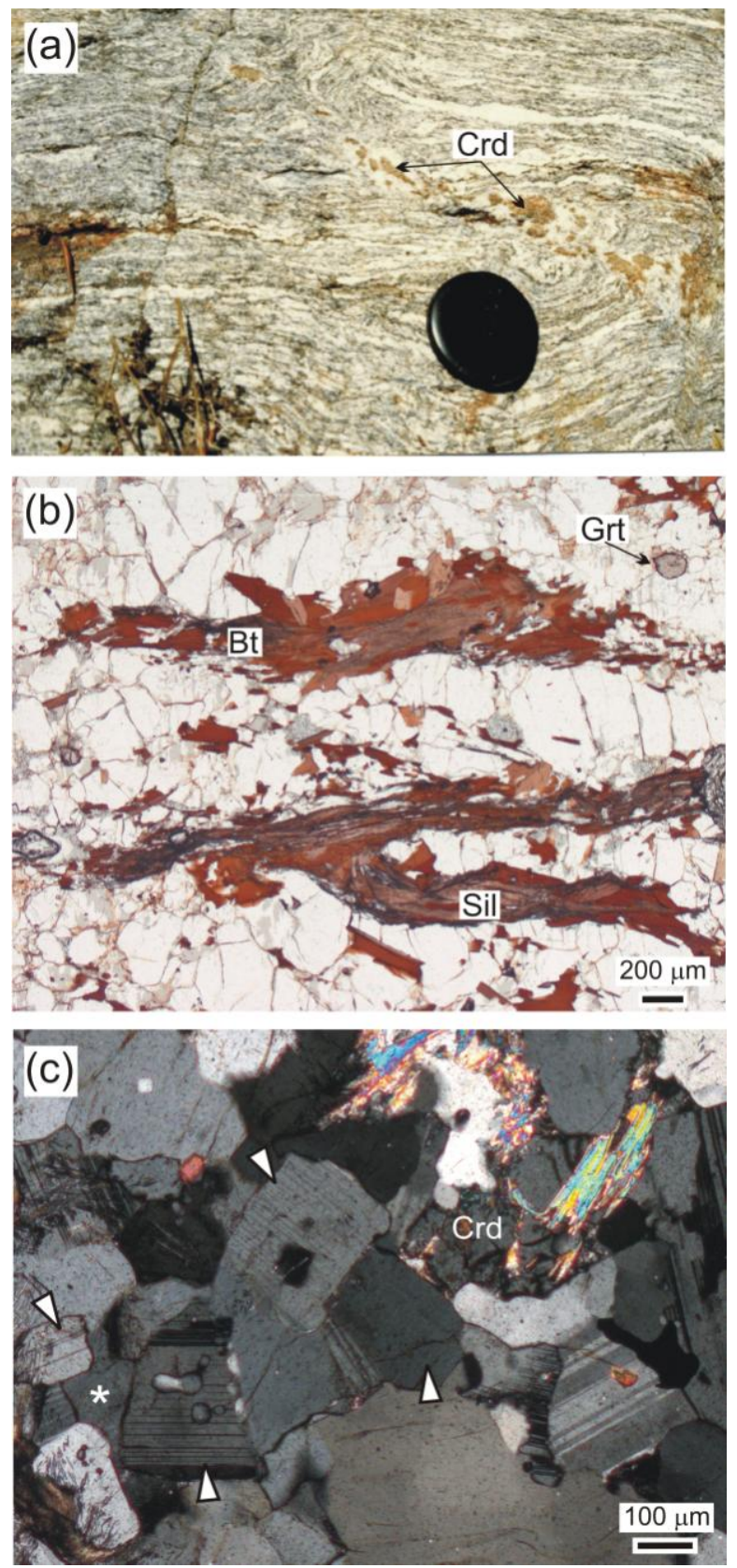

Figure 4 


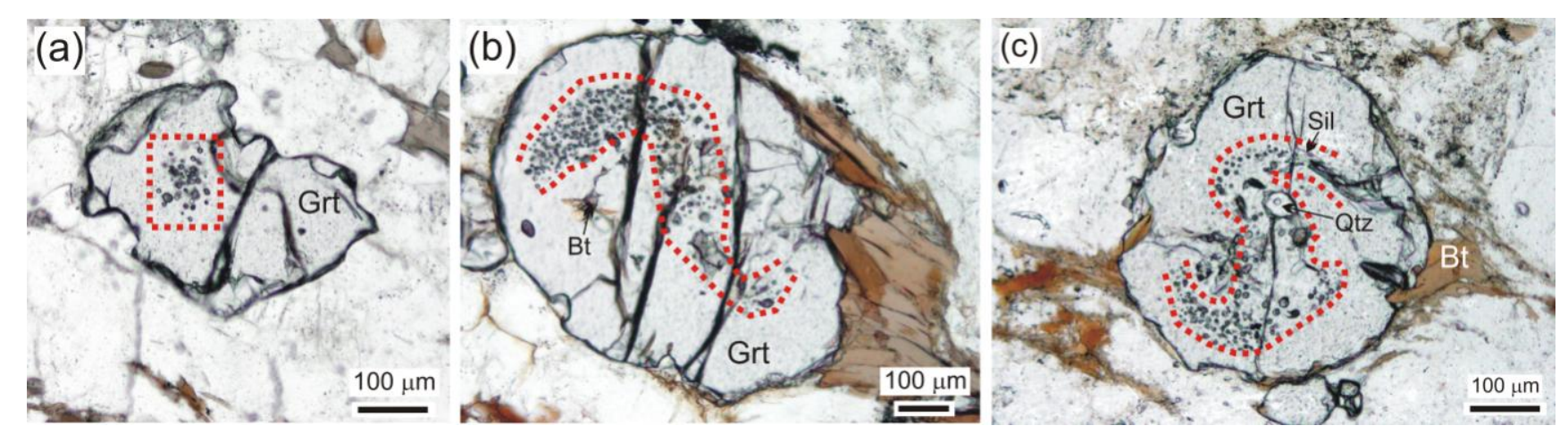

Figure 5 

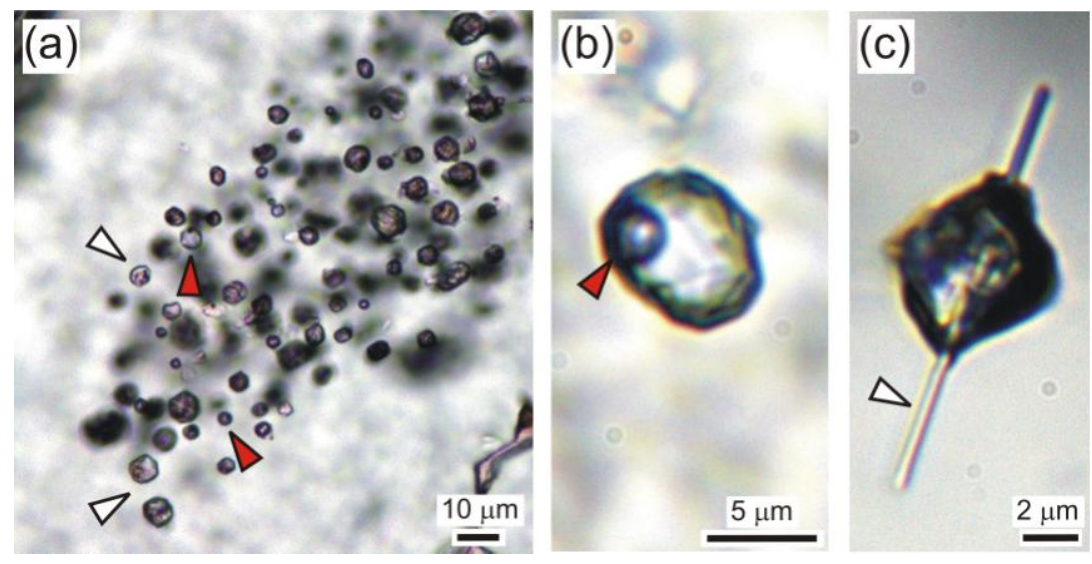

Figure 6 


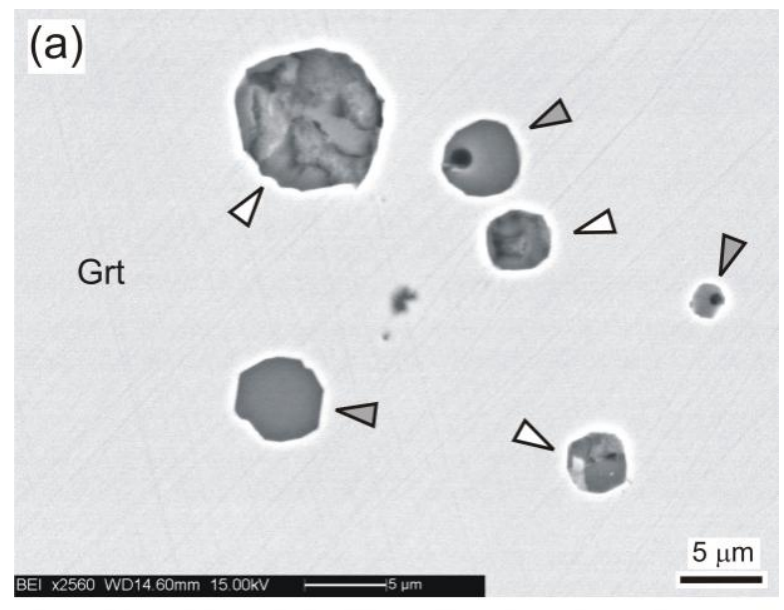

(b)

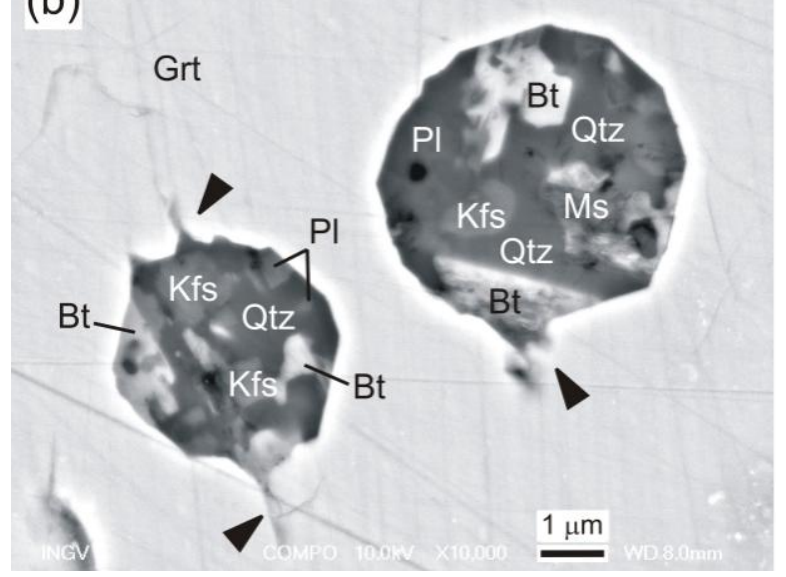

Figure 7 

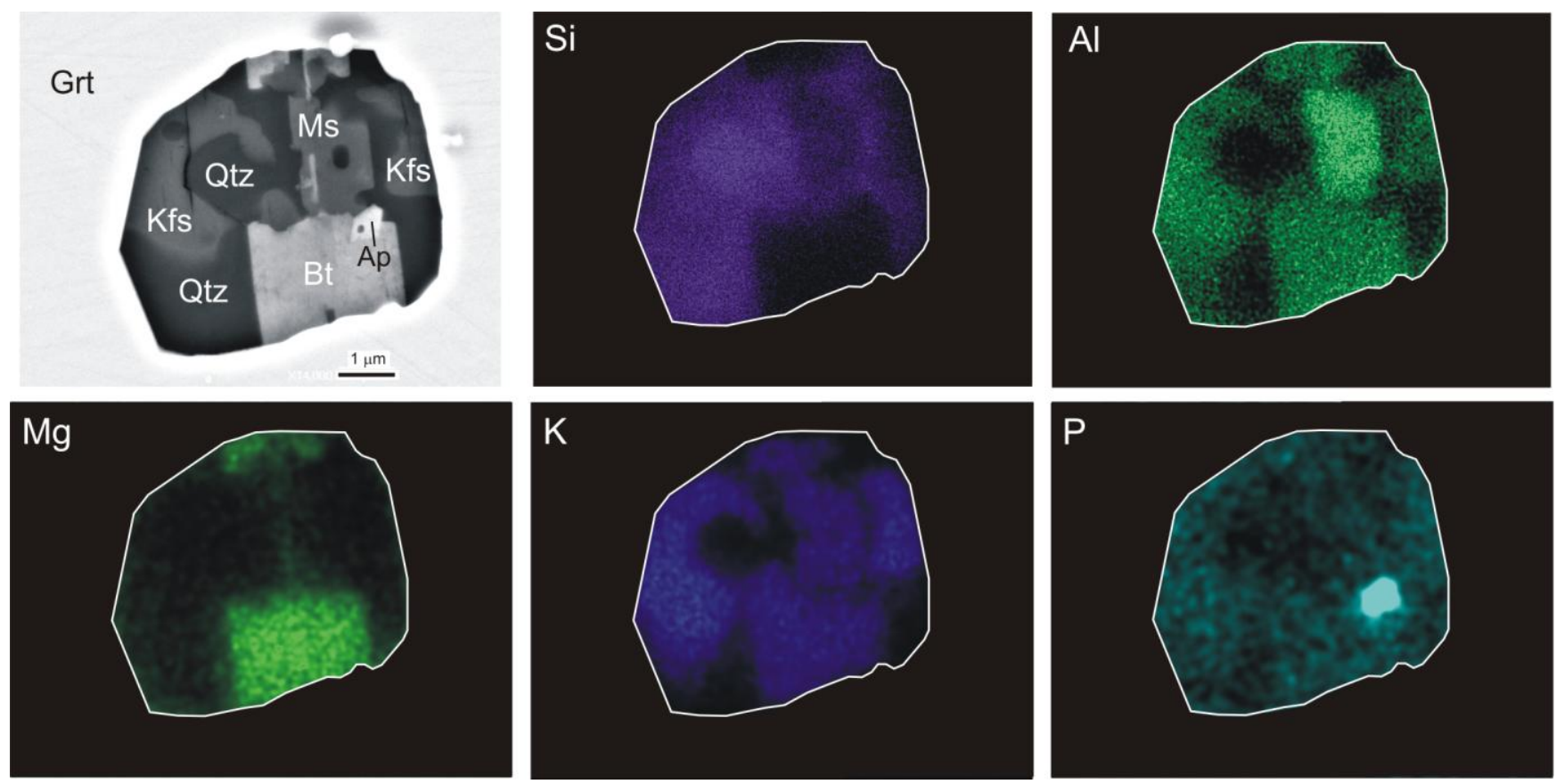

Figure 8 


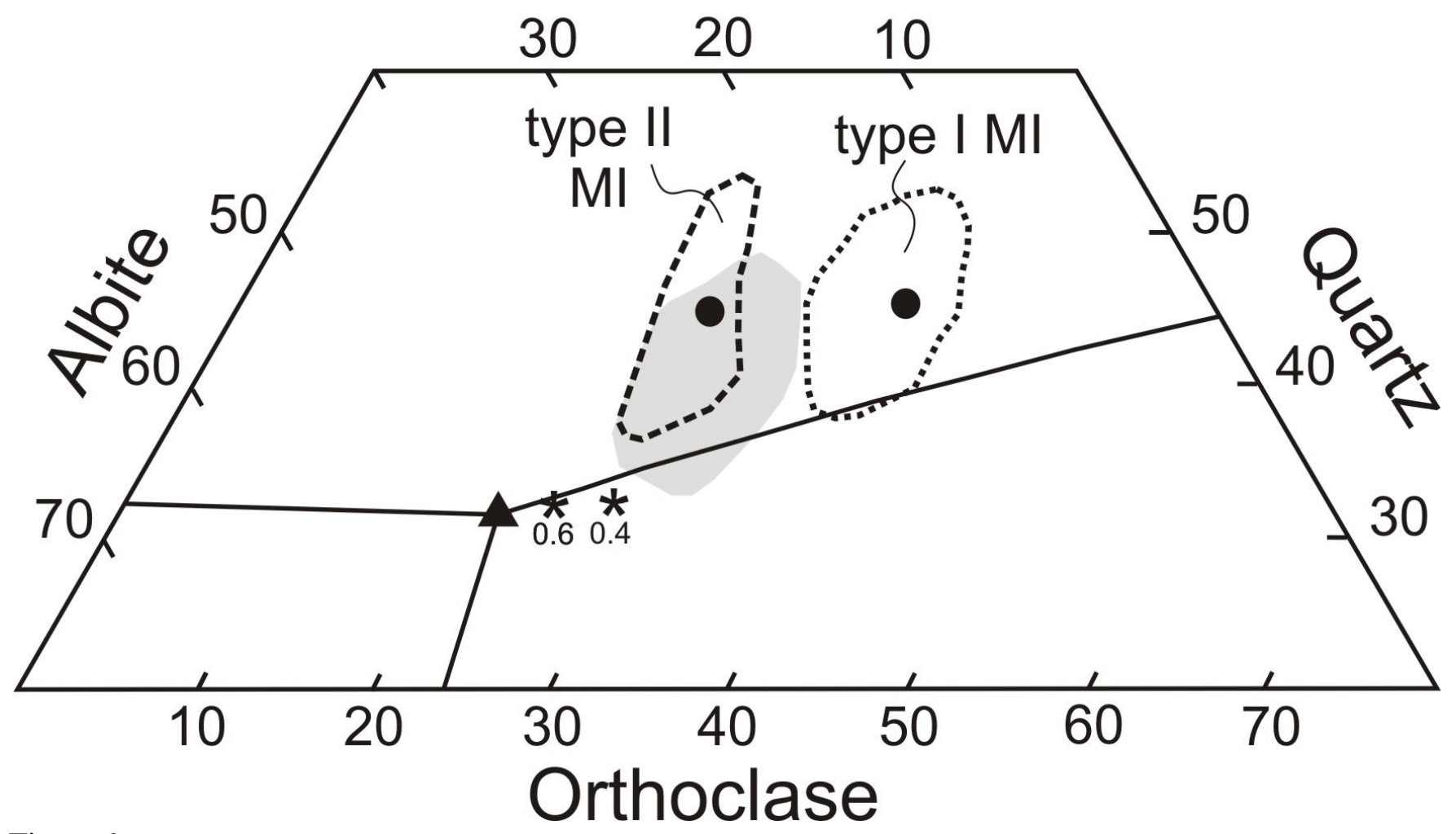

Figure 9 

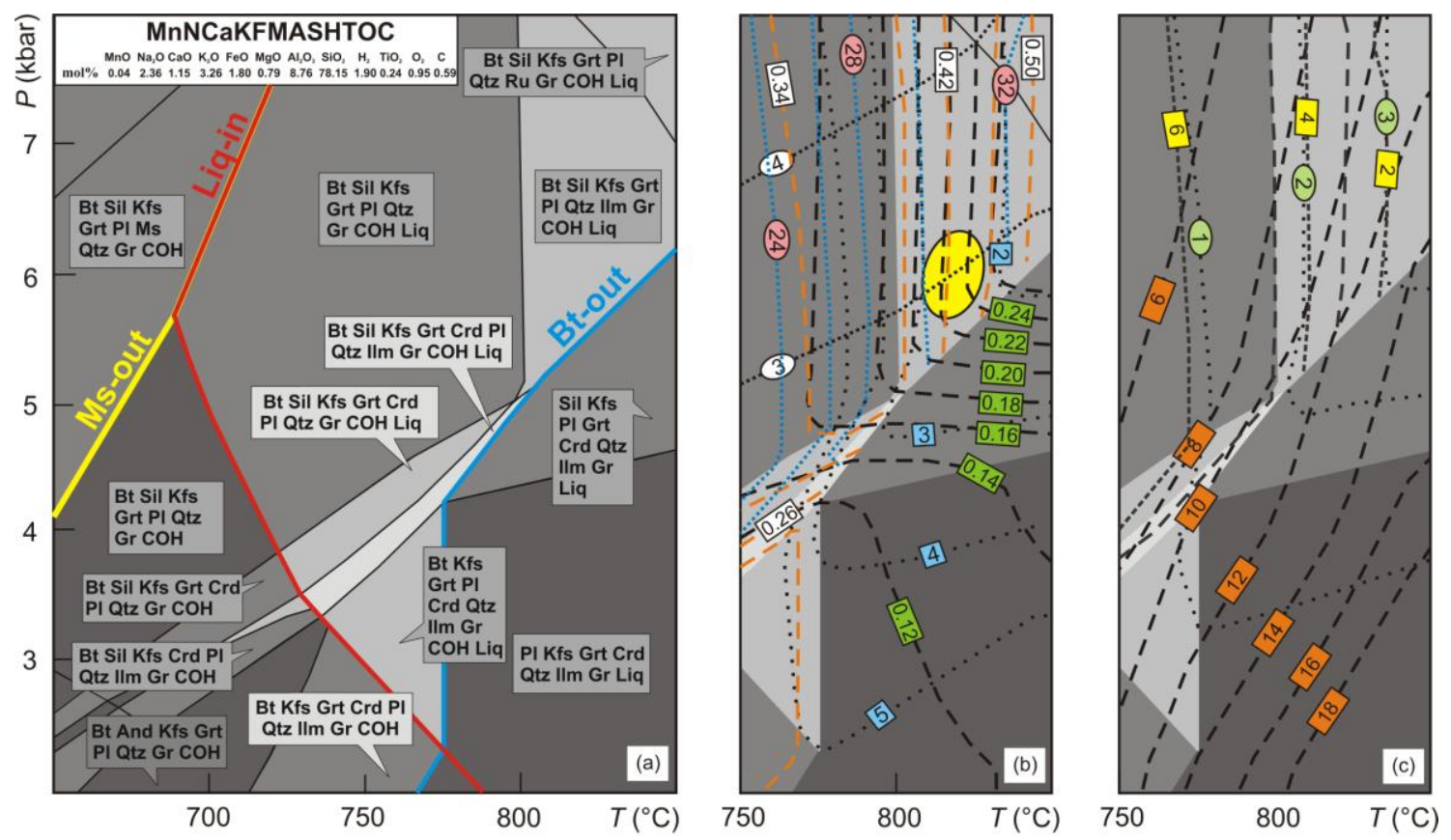

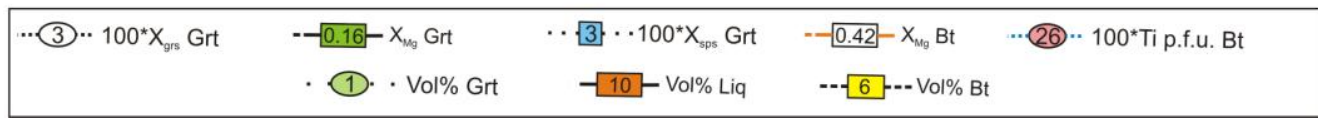

Figure 10 


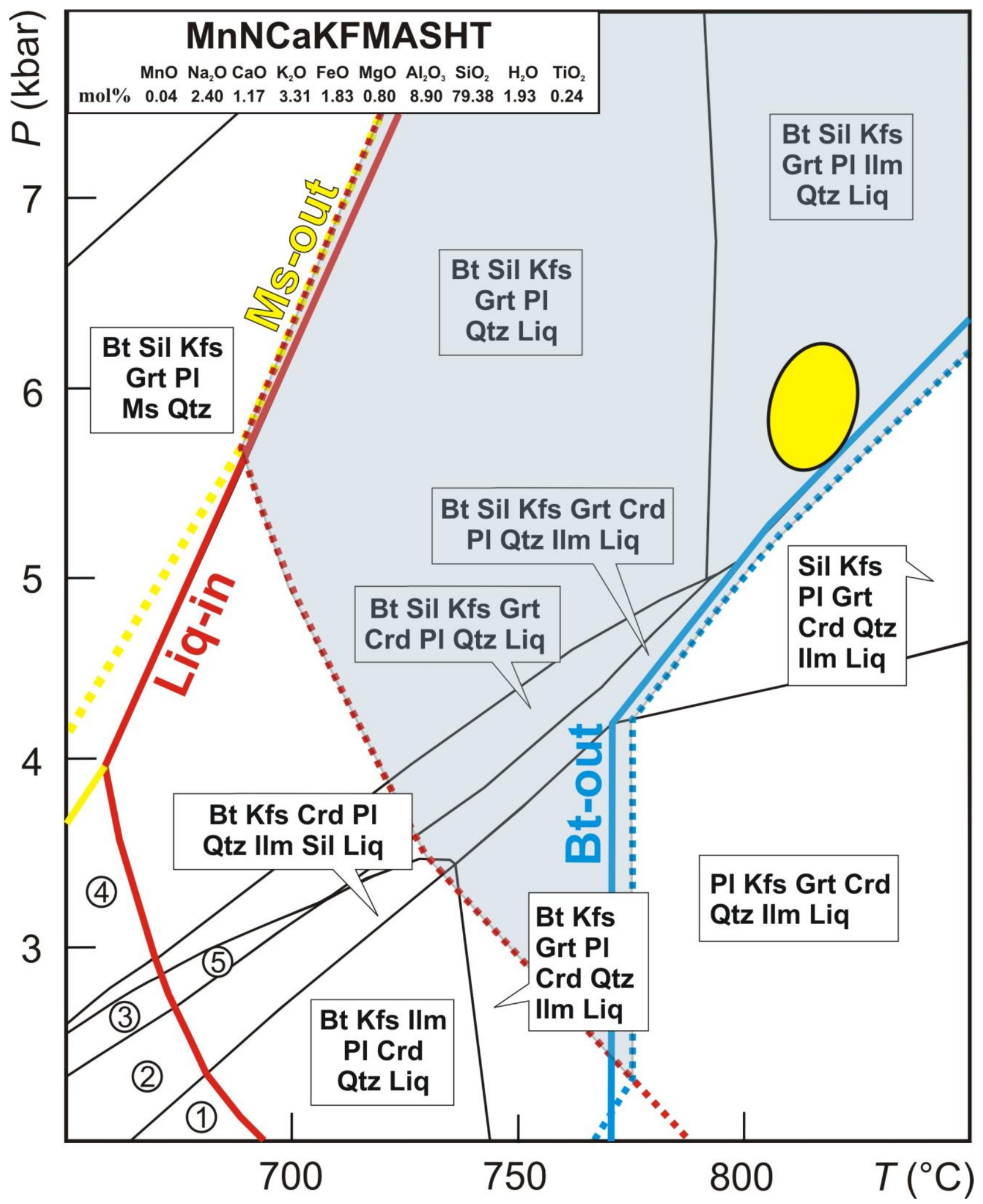

Figure 11 

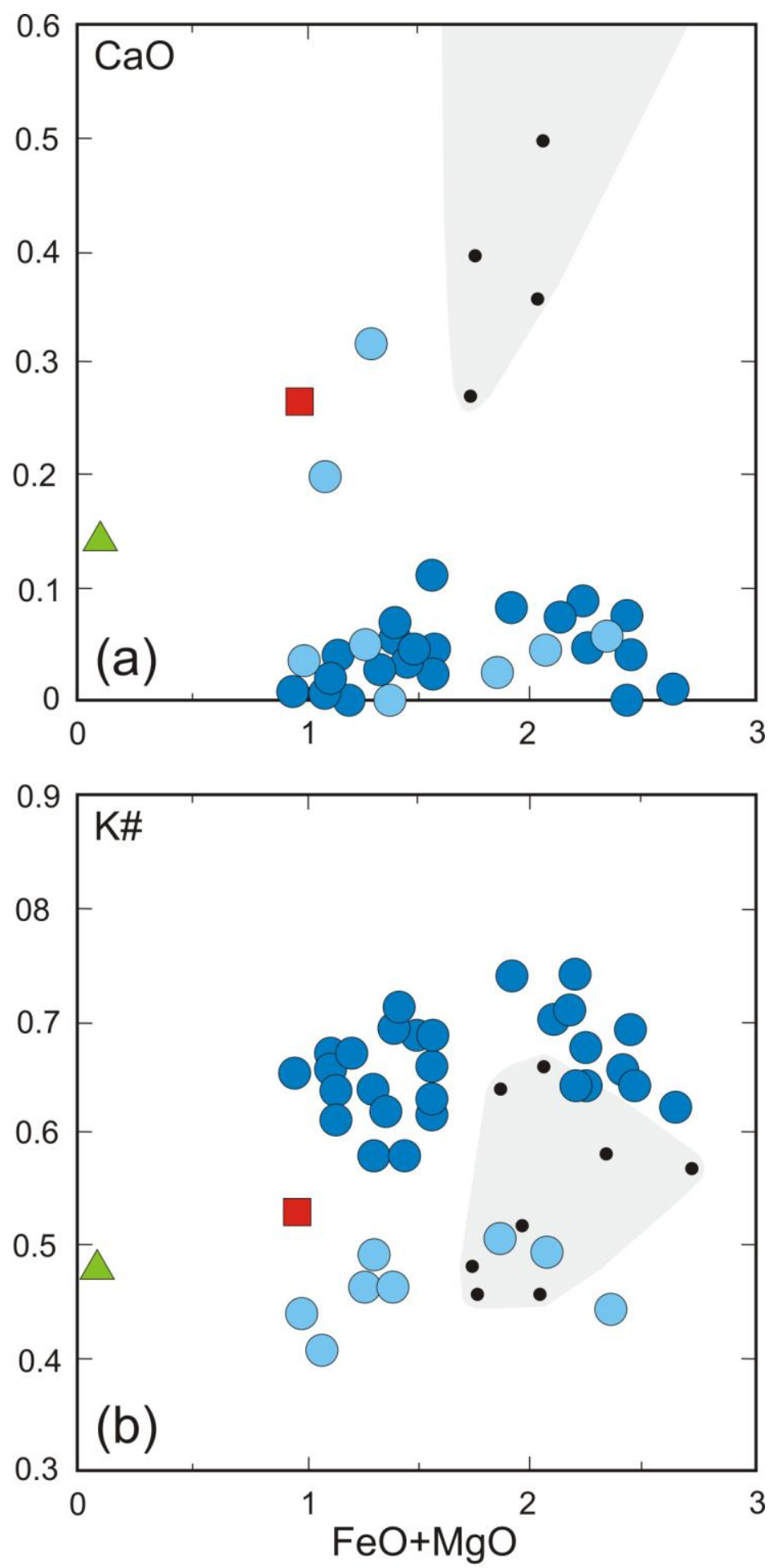

Type I MI $\square$ Calculated @ $820^{\circ} \mathrm{C}, 6$ kbar Type II MI $\triangle$ Calculated $@ 700^{\circ} \mathrm{C}, 6 \mathrm{kbar}$ - Experimental glasses

Figure 12 


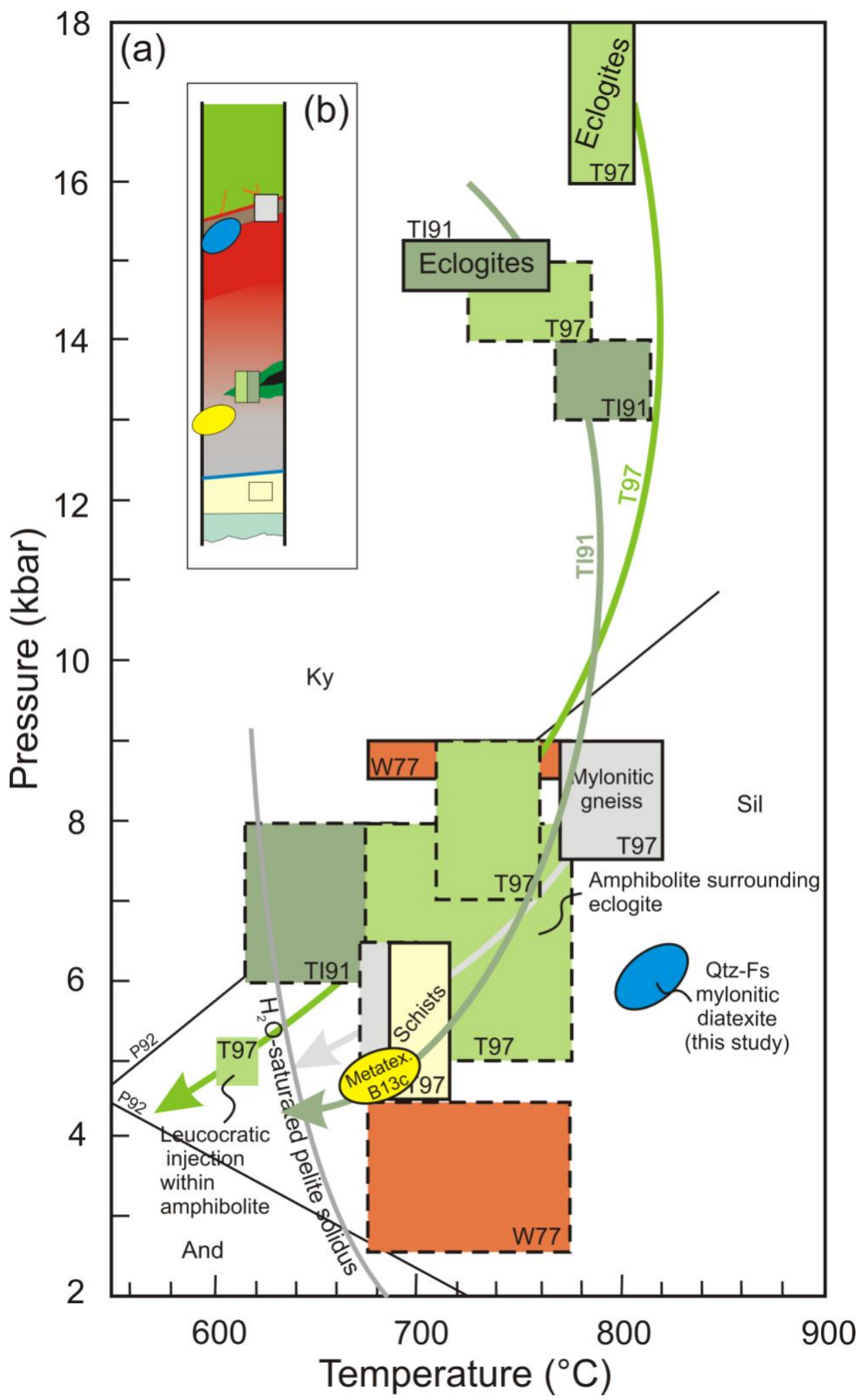

Figure 13 
Table 1. Electron microprobe analyses (wt\%) of minerals from mylonite ALP13 and bulk rock composition of quartzo-feldspathic migmatites.

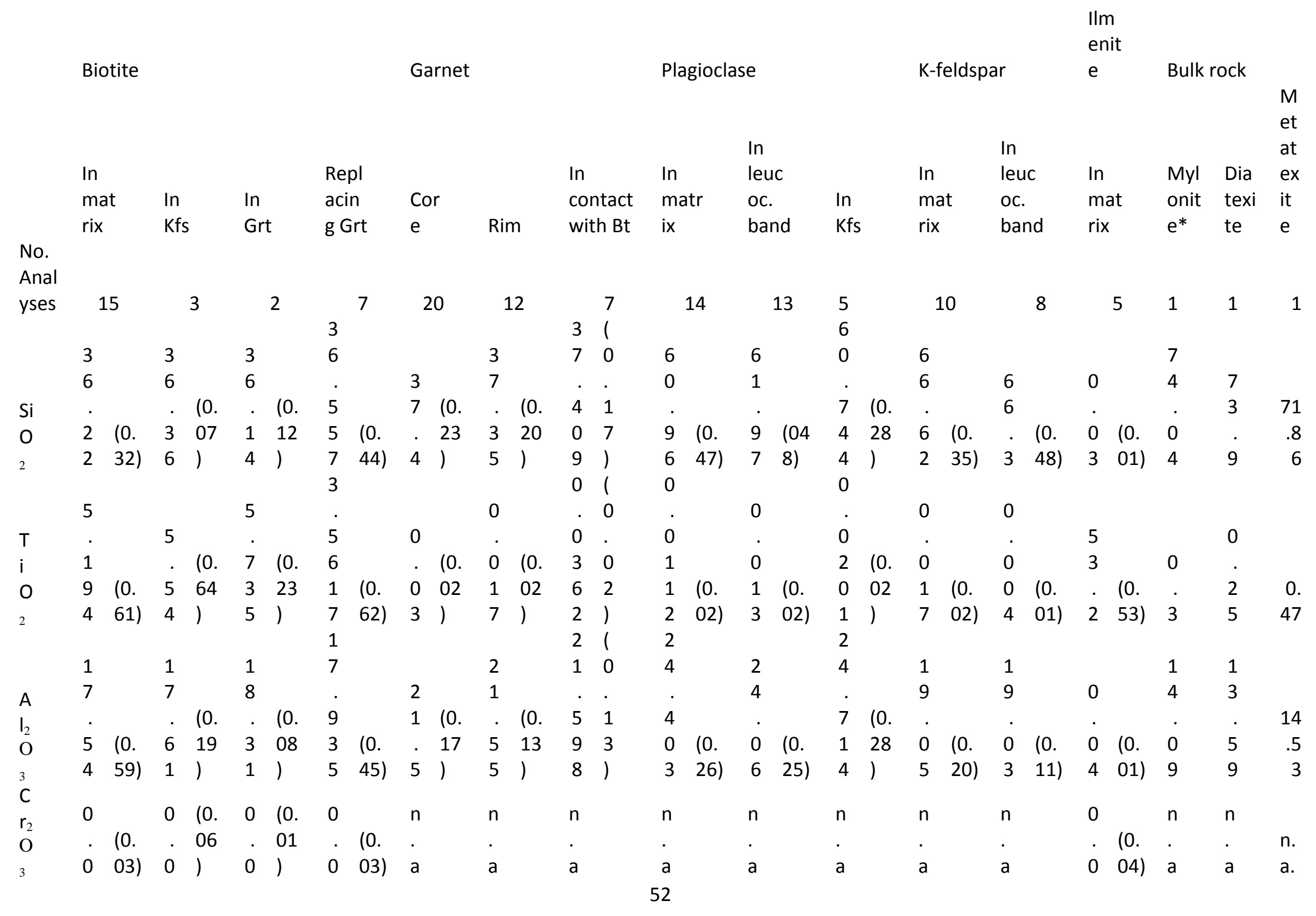




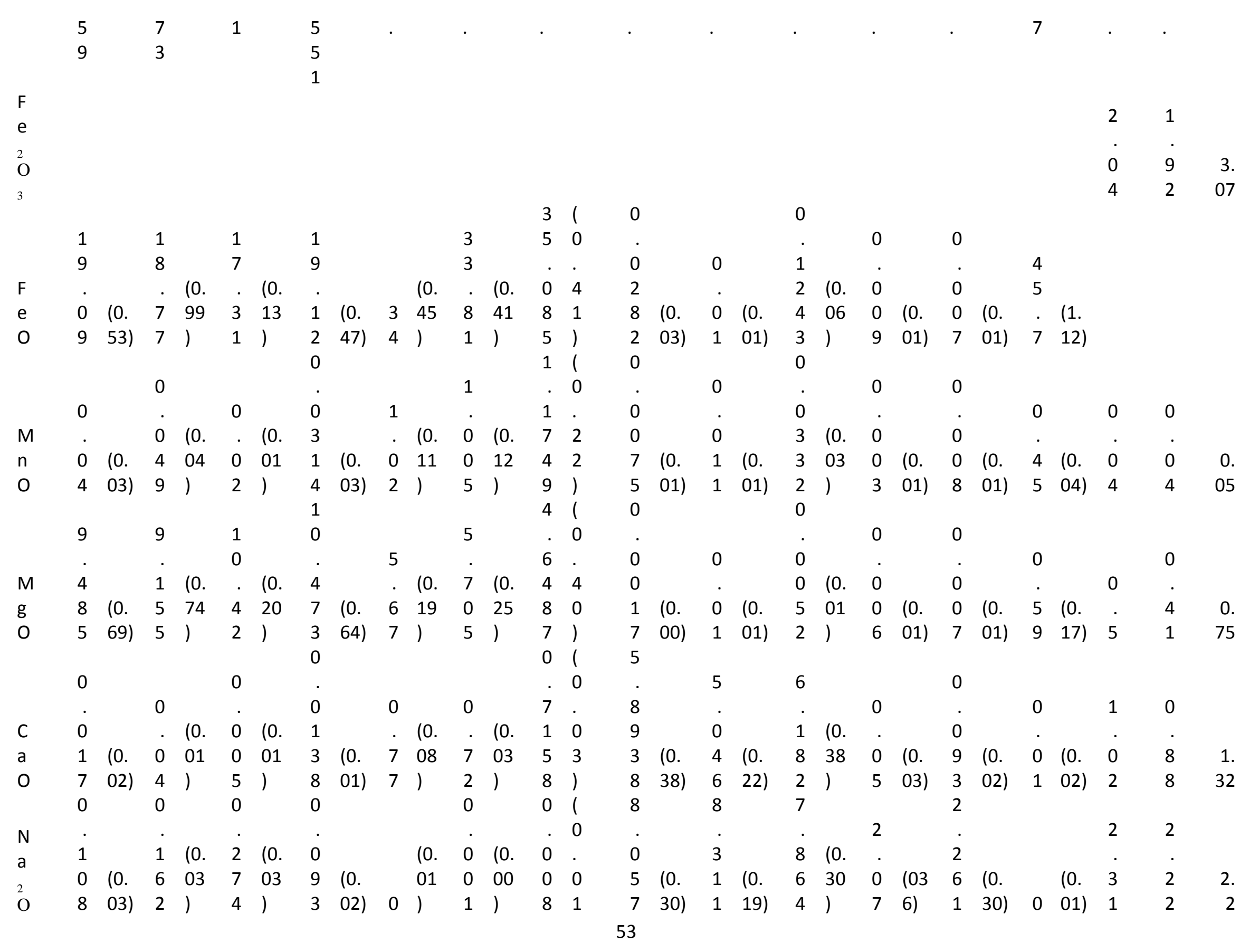




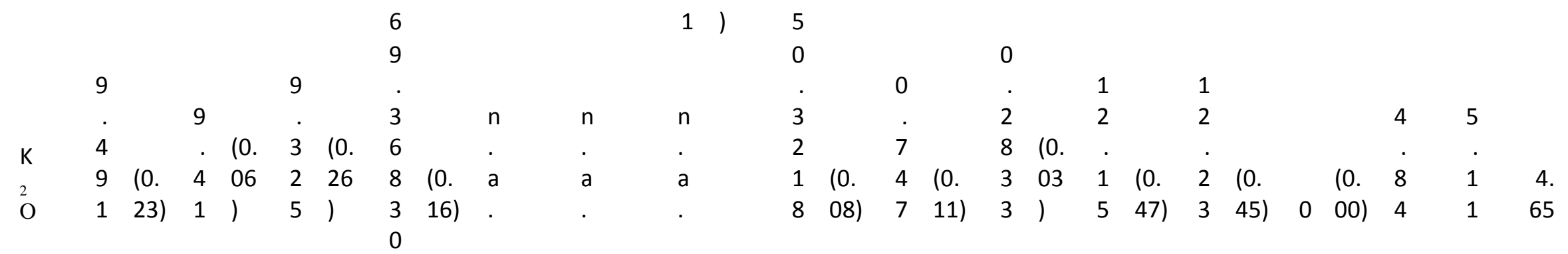

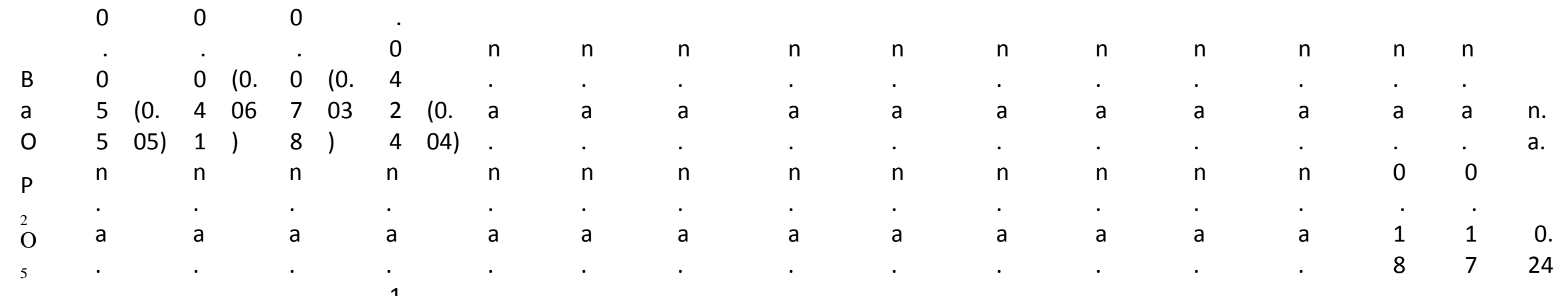

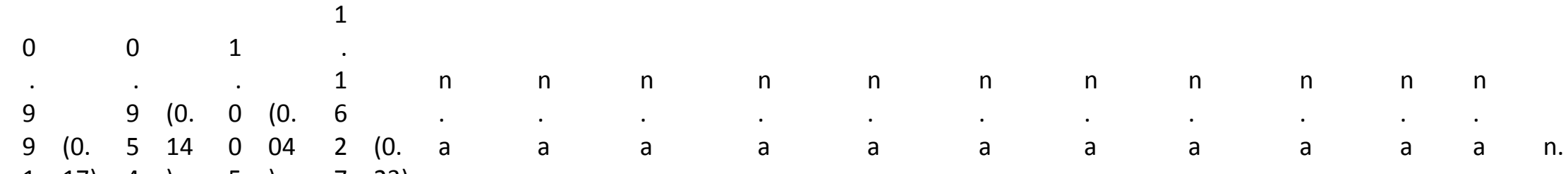

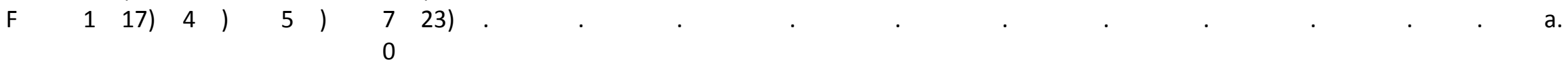

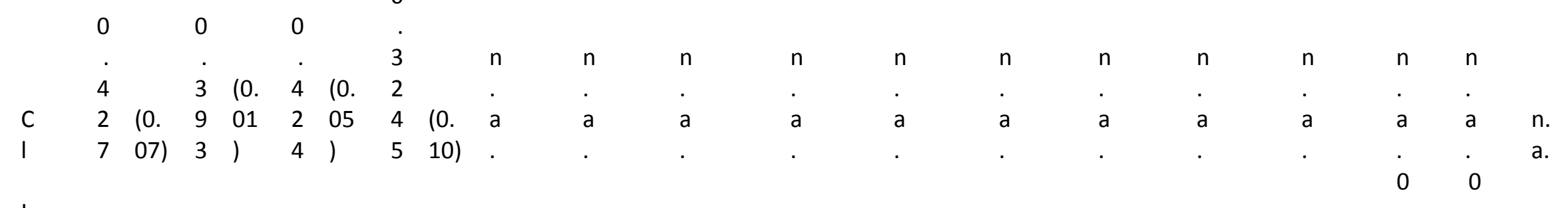

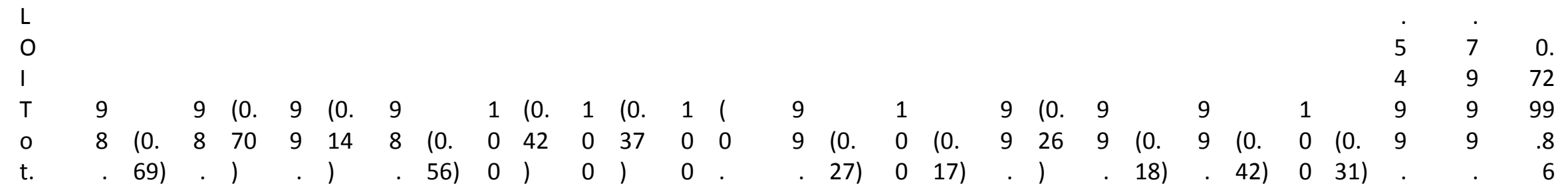




$$
\begin{aligned}
& \begin{array}{llllllllllllll}
7 & 5 & 0 & 7 & . & 5 & 6 & . & 9 & 9 & 9 & 9 & 2 \\
1 & 5 & 5 & 3 & 2 & 6 & 1 & 8 & 2 & 7 & 7 & 4 & & 8 \\
& & & 8 & & 7 & 1 & 4 & & & & &
\end{array}
\end{aligned}
$$

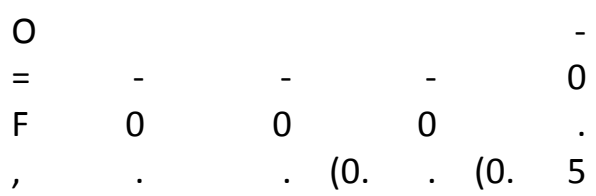

$$
\begin{aligned}
& \begin{array}{lllllllll}
\text { C } & 5 & (0 . & 4 & 05 & 5 & 00 & 6 & (0 .
\end{array} \\
& \begin{array}{lllllll} 
& 1 & 07) & 9 & \text { ) } & 3 & 08 \text { ) }
\end{array}
\end{aligned}
$$

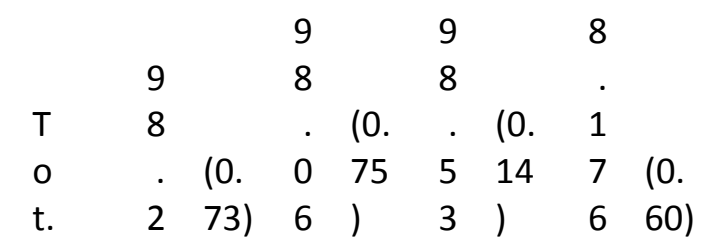

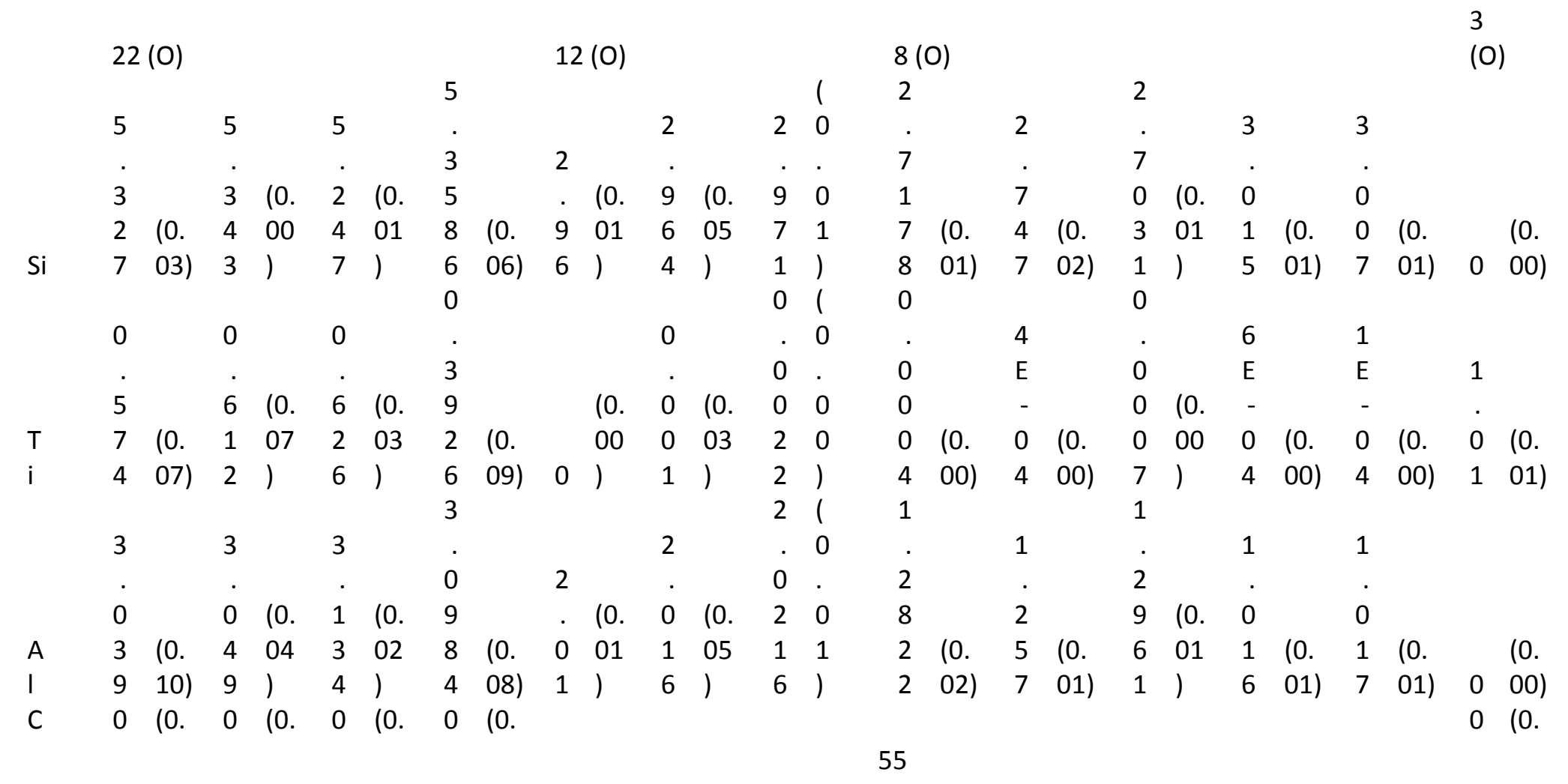




$$
\begin{aligned}
& \begin{array}{lllllllll}
r & . & 00) & . & 01 & . & 00 & . & 00) \\
0 & & 0 & 1 & 0 & 1 & 0 &
\end{array} \\
& \begin{array}{llll}
0 & 0 & 0 & 0 \\
7 & 8 & 1 & 6
\end{array} \\
& \begin{array}{r}
4 \\
2
\end{array}
\end{aligned}
$$

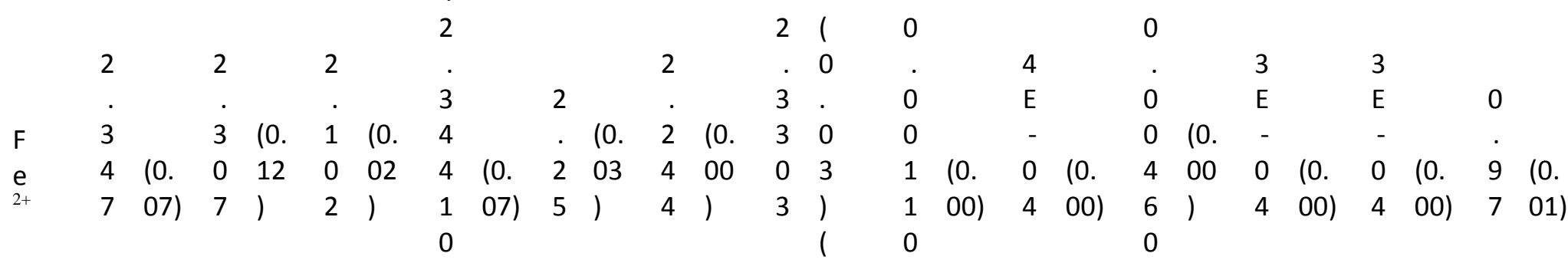

$$
\begin{aligned}
& \begin{array}{llllll}
0 & 0 & 0 & 0 & 0 & 0
\end{array}
\end{aligned}
$$

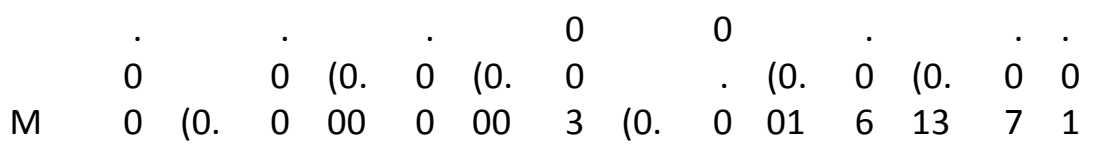

$$
\begin{aligned}
& \mathrm{n} 5500) 6 \text { ) } 2 \text { ) } 900) 7 \text { ) } 8 \text { ) } 9 \text { ) } \\
& \begin{array}{llllll}
5 & 2 & 2 & 0 & 0 & 1
\end{array}
\end{aligned}
$$

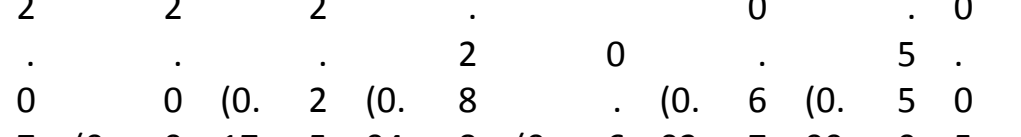

$$
\begin{aligned}
& \begin{array}{lllllllllllllll}
M & 7 & (0 . & 0 & 17 & 5 & 04 & 8 & (0 . & 6 & 02 & 7 & 00 & 0 & 5
\end{array} \\
& \begin{array}{lllllllllllllll}
\text { g } & 9 & 15) & 6 & \text { ) } & 6 & \text { ) } & 7 & 14) & 7 & 5 & \text { ) } & 4 & \text { ) }
\end{array} \\
& \begin{array}{lllllllll}
0 & 0 & 8 & . & 0 & . & 0 & . & 0
\end{array}
\end{aligned}
$$

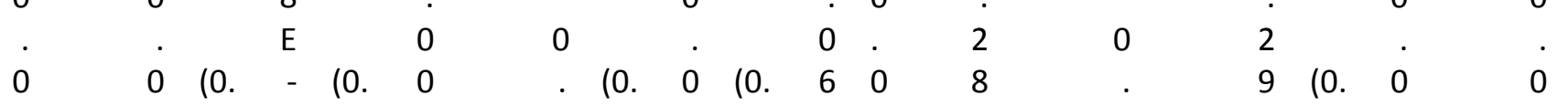

$$
\begin{aligned}
& \text { C } \quad \begin{array}{llllllllllllllllllllllllllll}
0 & (0 . & 0 & 00 & 0 & 00 & 2 & (0 . & 0 & 01 & 6 & 13 & 0 & 0 & 1 & (0 . & 2 & (0 . & 4 & 02 & 0 & (0 . & 0 & (0 . & 10 .
\end{array}
\end{aligned}
$$

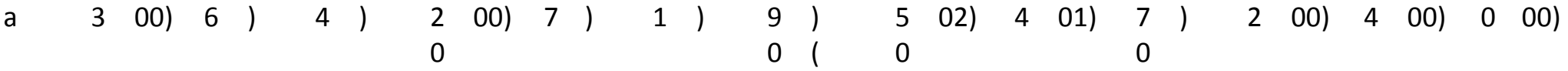

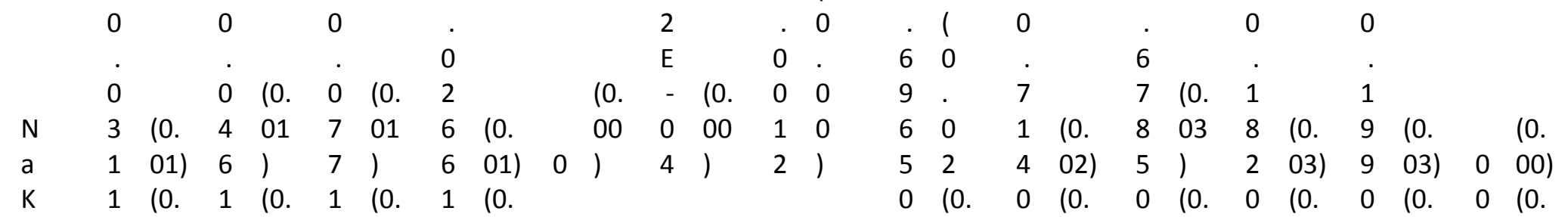




$$
\begin{aligned}
& \begin{array}{llllllll}
. & 04) & . & 01 & . & 05 & . & 03) \\
7 & & 7 & 1 & 7 & 1 & 7 & \\
8 & & 6 & & 2 & & 5 & \\
1 & & 4 & & 7 & & 2
\end{array} \\
& \begin{array}{lllllllllll}
. & 00) & . & 01) & . & 00 & . & 03) & \text {. } & 03) & 00) \\
0 & 0 & & 0 & 1 & 7 & & 7 & & \\
1 & 4 & & 1 & & 0 & & 0 & & \\
8 & 2 & & 6 & & 1 & & 8 & & \\
3 & & & 1 & & & & & &
\end{array}
\end{aligned}
$$

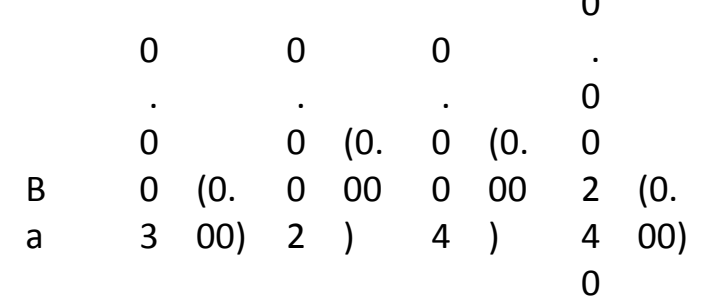

$$
\begin{aligned}
& \begin{array}{llll}
0 & & 0 & 3 \\
. & 0 & . & 3
\end{array} \\
& 3 \quad \text {. } 10 . \quad 2 \quad(0 . \quad 8 \\
& \begin{array}{lllllllll} 
& 2 & (0 . & 2 & 20 & 8 & 23 & 7 & (0 . \\
\mathrm{F} & 9 & 18) & 6 & ) & 4 & ) & 4 & 20)
\end{array} \\
& \begin{array}{llll}
0 & 0 & 0 & 0 \\
. & 0 & 0 & 0
\end{array} \\
& \begin{array}{llllll}
1 & 0 & 0 . & 1 & 0 . & 8
\end{array}
\end{aligned}
$$

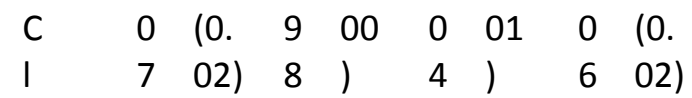

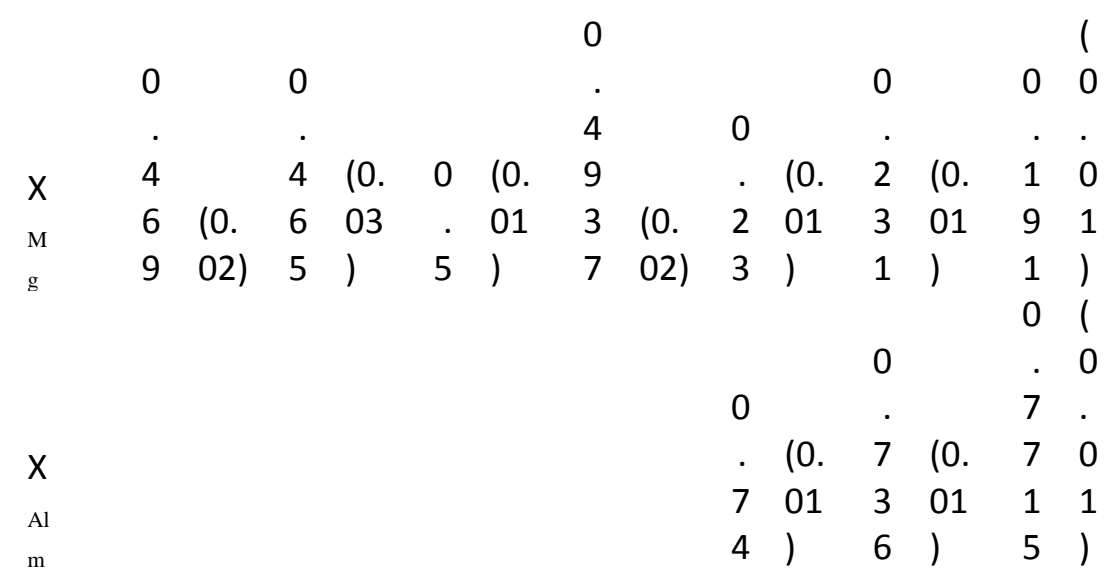




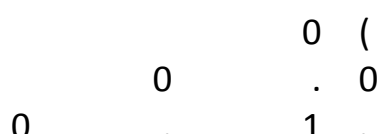

$$
\begin{aligned}
& \begin{array}{llllll}
0 & 0 . & 2 & 0 . & 8 & 0
\end{array} \\
& \begin{array}{llllll}
2 & 01 & 2 & 01 & 2 & 2
\end{array} \\
& 1 \text { ) } 1 \text {, } 2 \text { ) } \\
& 0 \quad 01 \\
& \begin{array}{llllll}
0 & & & & 0 & . \\
. & 0 . & 0 & 10 . & 2 & 0
\end{array} \\
& \begin{array}{llllll}
0 & 00 & 2 & 00 & 6 & 1
\end{array} \\
& 2 \text { ) 2) } 21 \\
& 01
\end{aligned}
$$

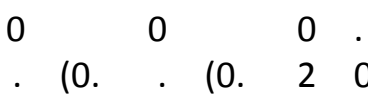

$$
\begin{aligned}
& \begin{array}{llllll}
\cdot & 10 . & . & 10 . & 2 & 0 \\
0 & 00 & 0 & 00 & 0 & 0
\end{array} \\
& 3 \text { ) } 2 \text {, } 2 \text { ) }
\end{aligned}
$$

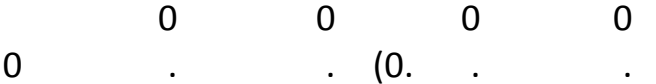

$$
\begin{aligned}
& \begin{array}{lllllllll}
\text { (0. } & 7 & (0 . & 6 & 02 & 2 & (0 . & 2 & 0 .
\end{array} \\
& \begin{array}{llllllllll}
7 & 02) & 2 & 01) & 9 & ) & 1 & 03) & 2 & 03
\end{array} \\
& . \quad 0 \quad 10 \\
& \begin{array}{lllllllll}
2 & 0 . & 2 & (0 . & . & 02 & (0 . & (0 .
\end{array} \\
& \begin{array}{llllllllll}
8 & 02) & 4 & 01) & 3 & ) & 0 & 00) & 0 & 00) \\
0 & & 0 & & 0 & & 0 & & 0 &
\end{array} \\
& \begin{array}{llllllllllll}
\hline 0 & 0 . & 0 & 0 . & 0 & 0 & 0 & 7 & 0 . & 7 & 0 .
\end{array}
\end{aligned}
$$

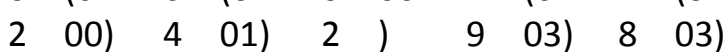


* Mylonitic diatexite ALP13 investigated in this study; n.a., not analyzed

${ }^{a}$ Alumina Saturation Index [=

mol. $\left.\mathrm{Al}_{2} \mathrm{O}_{3} /\left(\mathrm{CaO}+\mathrm{Na}_{2} \mathrm{O}+\mathrm{K}_{2} \mathrm{O}\right)\right]$ 
Table 2. Major element composition (wt\%) of glassy melt inclusions. Numbers in parentheses refer to $1 \sigma$ standard deviation.

\begin{tabular}{|c|c|c|c|c|}
\hline \multirow{3}{*}{$\begin{array}{l}\text { No. Analyses } \\
\mathrm{SiO}_{2}\end{array}$} & \multicolumn{2}{|c|}{ Type I } & \multicolumn{2}{|c|}{ Type II } \\
\hline & \multicolumn{2}{|c|}{31} & \multicolumn{2}{|l|}{8} \\
\hline & 76.33 & (1.48) & 75.97 & $(2.20)$ \\
\hline $\mathrm{TiO}_{2}$ & 0.05 & $(0.08)$ & 0.07 & $(0.07)$ \\
\hline $\mathrm{Al}_{2} \mathrm{O}_{3}$ & 11.35 & $(0.53)$ & 11.30 & $(0.73)$ \\
\hline $\mathrm{FeO}$ & 1.60 & $(0.50)$ & 1.34 & $(0.34)$ \\
\hline $\mathrm{MnO}$ & 0.06 & $(0.06)$ & 0.08 & $(0.08)$ \\
\hline $\mathrm{MgO}$ & 0.17 & $(0.11)$ & 0.15 & $(0.15)$ \\
\hline $\mathrm{CaO}$ & 0.07 & $(0.04)$ & 0.14 & $(0.17)$ \\
\hline $\mathrm{Na}_{2} \mathrm{O}$ & 1.96 & $(0.35)$ & 3.05 & $(0.51)$ \\
\hline $\mathrm{K}_{2} \mathrm{O}$ & 5.76 & $(0.36)$ & 3.98 & $(0.33)$ \\
\hline $\mathrm{P}_{2} \mathrm{O}_{5}$ & 0.23 & $(0.23)$ & 0.29 & $(0.29)$ \\
\hline Total & 97.58 & $(1.60)$ & 96.37 & $(1.08)$ \\
\hline $\mathrm{H}_{2} \mathrm{O}^{\mathrm{a}}$ & 2.42 & (1.60) & 3.63 & $(1.08)$ \\
\hline $\mathrm{ASI}^{\mathrm{b}}$ & 1.19 & $(0.10)$ & 1.19 & $(0.12)$ \\
\hline $\mathrm{Fe}+\mathrm{Mg}^{\mathrm{c}}$ & 0.03 & $(0.01)$ & 0.02 & $(0.01)$ \\
\hline $\mathrm{Na}_{2} \mathrm{O} / \mathrm{K}_{2} \mathrm{O}$ & 0.34 & $(0.06)$ & 0.77 & $(0.11)$ \\
\hline $\mathrm{K} \#^{\mathrm{d}}$ & 0.66 & $(0.04)$ & 0.46 & $(0.03)$ \\
\hline \multicolumn{5}{|c|}{ Calculated normative mineralogy } \\
\hline Qtz & 41.26 & $(2.68)$ & 41.56 & $(5.06)$ \\
\hline Crn & 1.86 & $(0.89)$ & 1.91 & $(1.02)$ \\
\hline Or & 34.02 & $(2.15)$ & 23.50 & $(1.95)$ \\
\hline $\mathrm{Ab}$ & 16.56 & $(2.98)$ & 25.84 & $(4.29)$ \\
\hline An & 0.13 & $(0.22)$ & 0.18 & $(0.23)$ \\
\hline
\end{tabular}

${ }^{a}$ The $\mathrm{H}_{2} \mathrm{O}$ content of MI is calculated by difference on the EMP total after alkali loss correction

${ }^{\mathrm{b}}$ Alumina Saturation Index $\left[=\right.$ mol. $\left.\mathrm{Al}_{2} \mathrm{O}_{3} /\left(\mathrm{CaO}+\mathrm{Na}_{2} \mathrm{O}+\mathrm{K}_{2} \mathrm{O}\right)\right]$

${ }^{\mathrm{c}}$ Maficity index (see Villaros et al., 2009)

${ }^{\mathrm{d}} \mathrm{K} \#=$ mol. $\mathrm{K}_{2} \mathrm{O} /\left(\mathrm{Na}_{2} \mathrm{O}+\mathrm{K}_{2} \mathrm{O}\right)$ 